\title{
Geological mapping of Mesozoic deposits along the eastern margin of the Rønne Graben, offshore Bornholm, Denmark
}

\author{
JØRN BO JENSEN and NIELS ERIK HAMANN
}

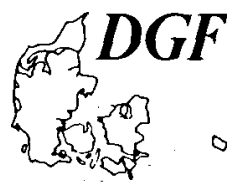

\begin{abstract}
Jensen, J. B. and Hamann, N. E.: Geological mapping of Mesozoicdeposists along the eastern margin of the Rønne Graben, offshore Bornholm, Denmark. Bull. geol. Soc. Denmark, Vol. 37, pp. 237-260. Copenhagen, April 10th, 1989. https://doi.org/10.37570/bgsd-1988-37-19

Detailed shallow seismic investigations of the eastern Rønne Graben, offshore Bornholm have resulted in the recognition of characteristic seismic facies which are subdivided into seismostratigraphic units.

The seismostratigraphic units are correlated with known lithostratigraphic units on Bornholm, thus permitting detailed geological mapping along the eastern margin of the Rønne Graben.

In contrast to the sequence on Bornholm, it appears that there was continuous sedimentation from the Rønne Formation (Lower Jurassic) to the Rabekke Formation (Lower Cretaceous), while the Robbedale and Jydegård Formations (Lower Cretaceous) are absent in the Rønne Graben. In the area mapped in detail the youngest Pre-Quaternary sediments are the Arnager Greensand, the Arnager Limestone and the Bavnodde Greensand Formations (Upper Cretaceous).

All the Mesozoic deposits were affected by transpressional tectonic activity during the Upper Cretaceous - Lower Tertiary.

The structural relationships show a characteristic pattern consisting of the main fault on the eastern side of the Rønne Graben and a system of en échelon reverse faults. This pattern probably formed as a result of northeast-southwest wrench movements in a compressional dextral strike slip system.
\end{abstract}

Jørn Bo Jensen and Niels Erik Hamann, Ministry of Environment. The National Forest and Nature Agency. The Marine Raw Material Survey Division, Slotsmarken 13, 2970 Hørsholm, Denmark. Hørsholm July 20th 1988.

\section{Introduction}

The geology of Bornholm has long attracted attention and, in particular the Mesozoic sedimentary succession has been studied in some detail.

The Mesozoic stratigraphy was studied by Gry (1956, 1960, 1968 and 1969), while the present lithostratigraphic subdivision was established by Gravesen et al. (1982). The literature on the Mesozoic deposits of Bornholm is extensive, as can be seen from the reference lists in earlier publications (Gry, 1969; Gravesen et al., 1982).

The results of general investigations of the block units around Bornholm have been published by Andersen et al. (1975), but offshore studies were not intensified until deep seismic studies were carried out in the search for oil (Vejbæk, 1985; Liboriussen et al., 1987).

. In addition, shallow seismic studies have been carried out in connection with the search for sand and gravel deposits. These studies have included both general investigations (Larsen, 1986; Ha- mann, 1987a; Hamann, 1987b) and detailed studies (Jensen, 1988a; Jensen, 1988b).

This paper presents results from a detailed study on the eastern flank of the Rønne Graben.

\section{Bornholm - Part of the Fennoscandian Border Zone}

The Fennoscandian Border Zone is a complex tectonic zone (fig. $1 \& 2$ ) along which there has been tectonic activity from Late Carboniferous times to the present day.

Bornholm is located on the southern margin of the Fennoscandian Border Zone, and the existence of Bornholm as an island can be ascribed to movements along this zone. Deep seismic studies (Liboriussen et al., 1987) show that the Rønne Graben was initiated between Carboniferous and Permian times and developed as a pull apart basin, formed by right stepping associated with dextral wrench along the Fennoscandian Border Zone (Vejbæk, 1985). 


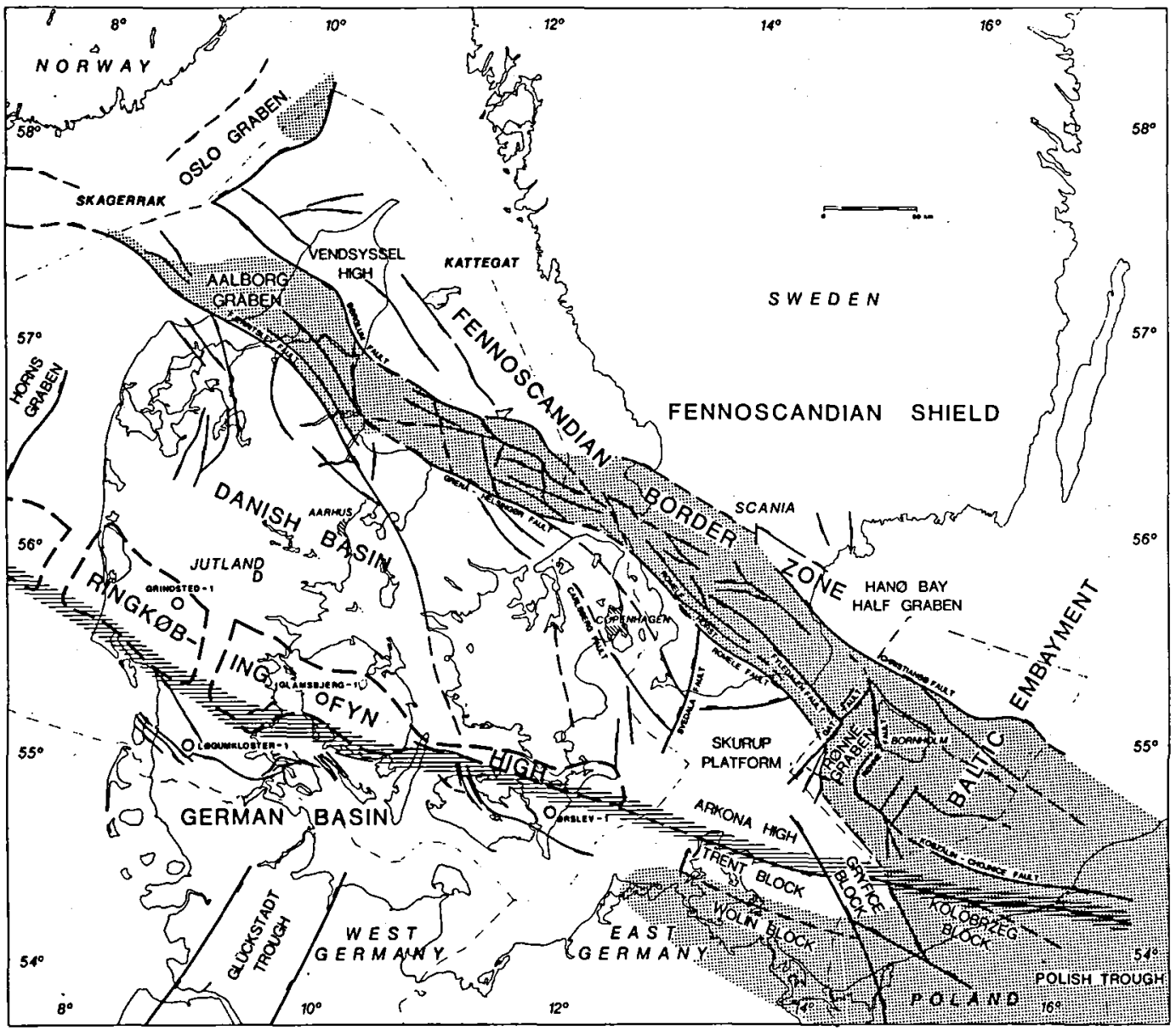

\section{LEGEND}

\section{- FAULT ( Showing pro-inversion throw ) - - RINGKøBING FYN HIGH OUTLINE \\ O WELL LOCATION}

\section{CALEDONIAN DEFORMATION FRONT AREAS OF LATE CRETACEOUS / EARLY TERTIARY INVERSION}

Fig. 1. Tectonic map of the Fennoscandian Border Zone (after Liboriussen et al., 1987).

The Fennoscandian Border Zone was activated several times during the Mesozoic rift phase (Triassic - Jurassic), resulting in differential subsidence of the Rønne Graben. This subsidence, in combination with eustatic sea level variations, were the dominant factors controlling of deposition during this period (Gravesen et al., 1982).

Transtensional movements in Triassic-Early Cretaceous times were replaced in the latest Cretaceous - Early Tertiary by transpressional movements, probably related to early Alpine plate collision (Ziegler, 1981).

The transpressional movements reactivated faults along the Fennoscandian Border Zone, mainly as reverse faults in a dextral strike-slip regime, resulting in partial uplift of the Fennoscandian Border Zone (Liboriussen et al., 1987). This inversion is clearly shown by deep seismic studies in the Rønne Graben (fig. 1).

The shallow seismic studies show that this inversion phase occured after deposition of the Bavnodde Greensand Formation (fig. 5 \& 11) since these deposits were folded during reverse fault movements.

It is also clear that the Bavnodde Greensand Formation is present over a large area of the sea 


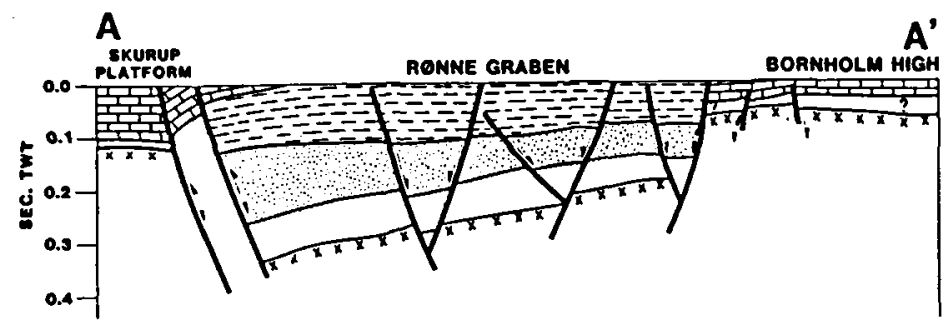

堊空 U. CAETACEOUS/CAHOZOIC

E- L. CAETACEOUS/JUAAssic

ramissic

DPALAEOZOIC

$x^{x} x^{x} x$ Basement
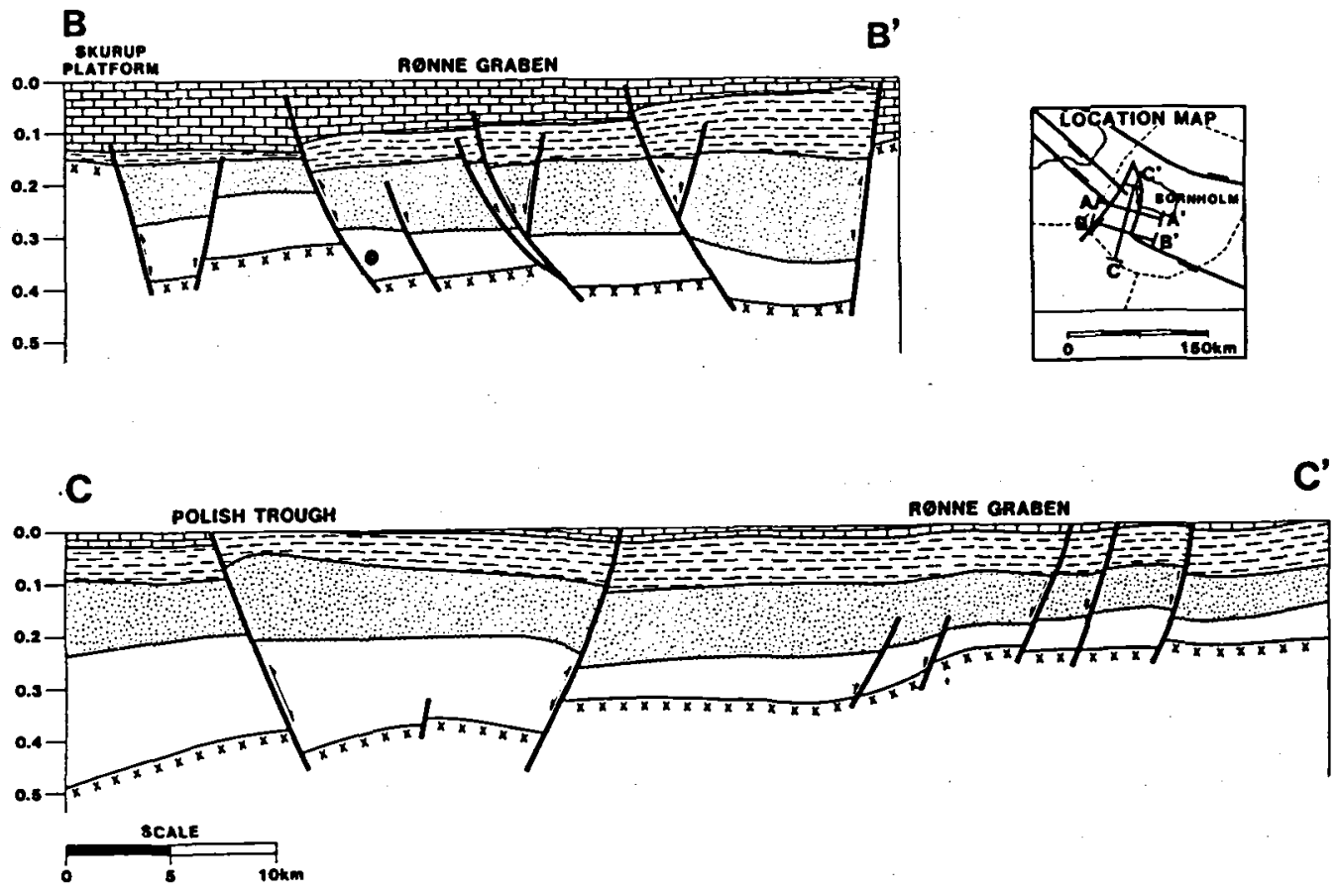

Fig. 2. Interpreted deep seismic profiles across the Rønne Graben (after Liboriussen et al., 1987).

floor (Hamann, 1987a), whereas the Pre-Quaternary deposits elsewhere are discordantly overlain by Quaternary deposits which are apparently undeformed (fig. 14).

\section{Shallow seismic studies}

Marine geological mapping in the area south of Bornholm (fig. 3a) was carried out in 1983 as part of a project to map the distribution of sand and gravel around Denmark. The mapping involved shallow seismic reflection investigations and sampling.

The aim was to establish the distribution of quartz sand, and detailed geological mapping of the Mesozoic deposits was carried out in a small area on the Arnager-Sose block (enclosure A5 in Larsen, 1986).

A series of sand excavations were carried out on the basis of the general mapping. Together with reinterpretation of the seismic data, this led to the publication of a regional geological map showing the distribution of Mesozoic deposits in the area (Hamann, 1987a).

Study of this geological data showed however, that the structure was so complicated that detailed reflection seismic prospecting was required to map the distribution of quartz sand resources in the area west of the town of Rønne (fig. 3a).

This investigation was carried out in the sum- 
a

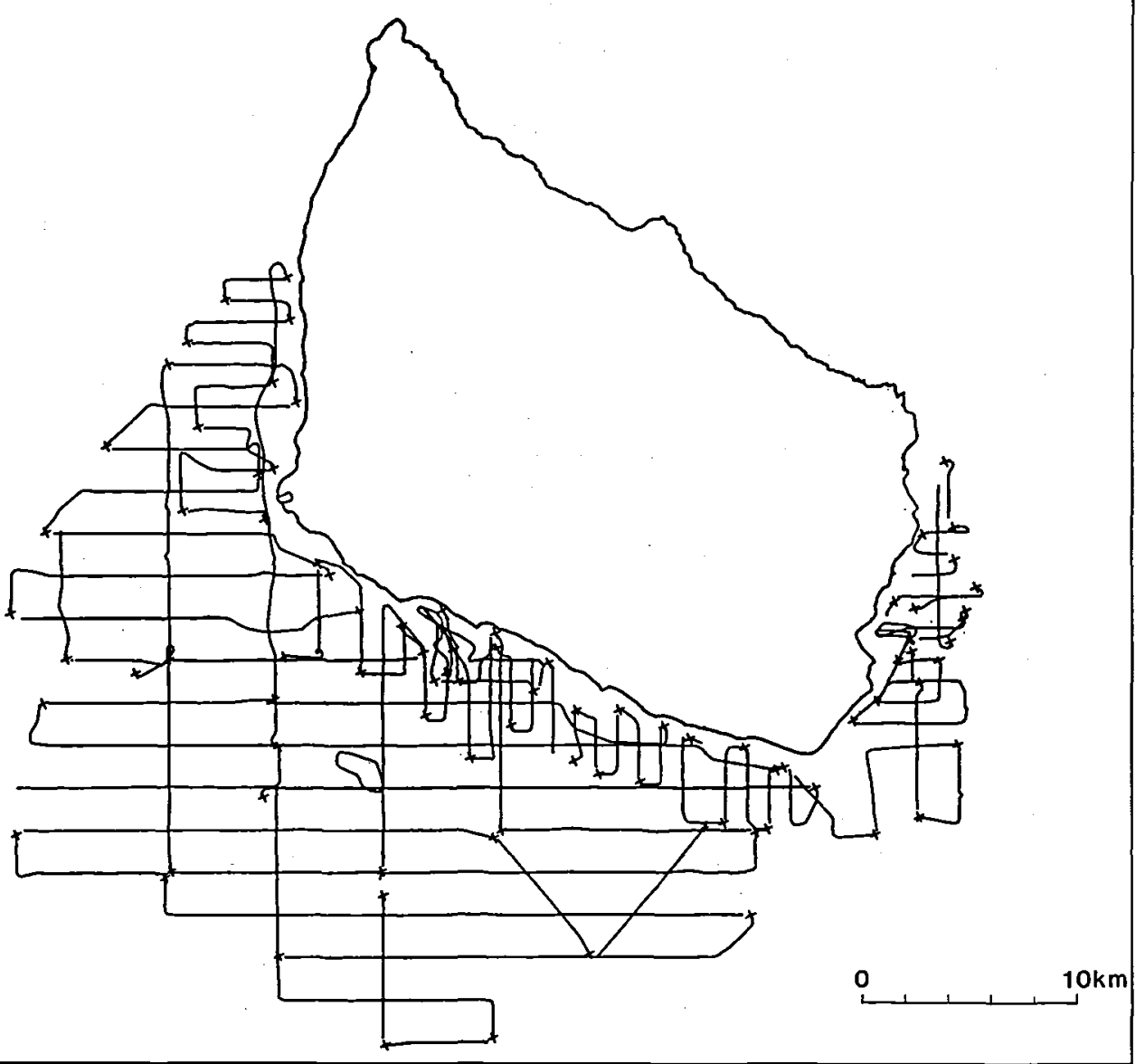

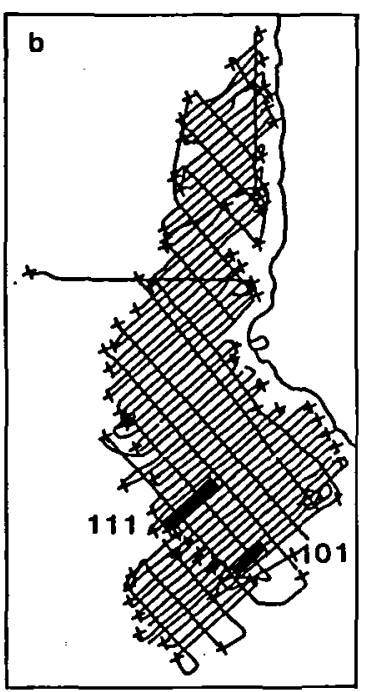

0

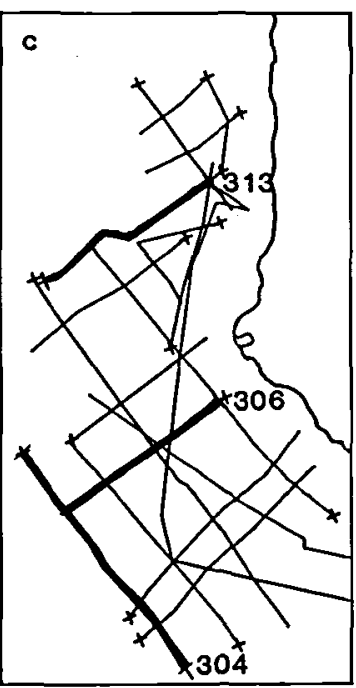

$10 \mathrm{~km}$
Fig. 3. Shallow seismic reflection sailing lines.

Fig. 3a. General investigations (echo sounding, pinger, boomer and side scan sonar).

Fig. 3b. Detailed investigations (echo sounding, pinger, boomer and side scan sonar).

The lines numbered 101 and 111 refer to figures $9 a, b$ and 13a, b.

Fig. 3c. Detailed investigations (subbottom profiles and air gun).

The lines numbered 304, 306 and 313 refer to figures 11, 12 and 14 respectively. 


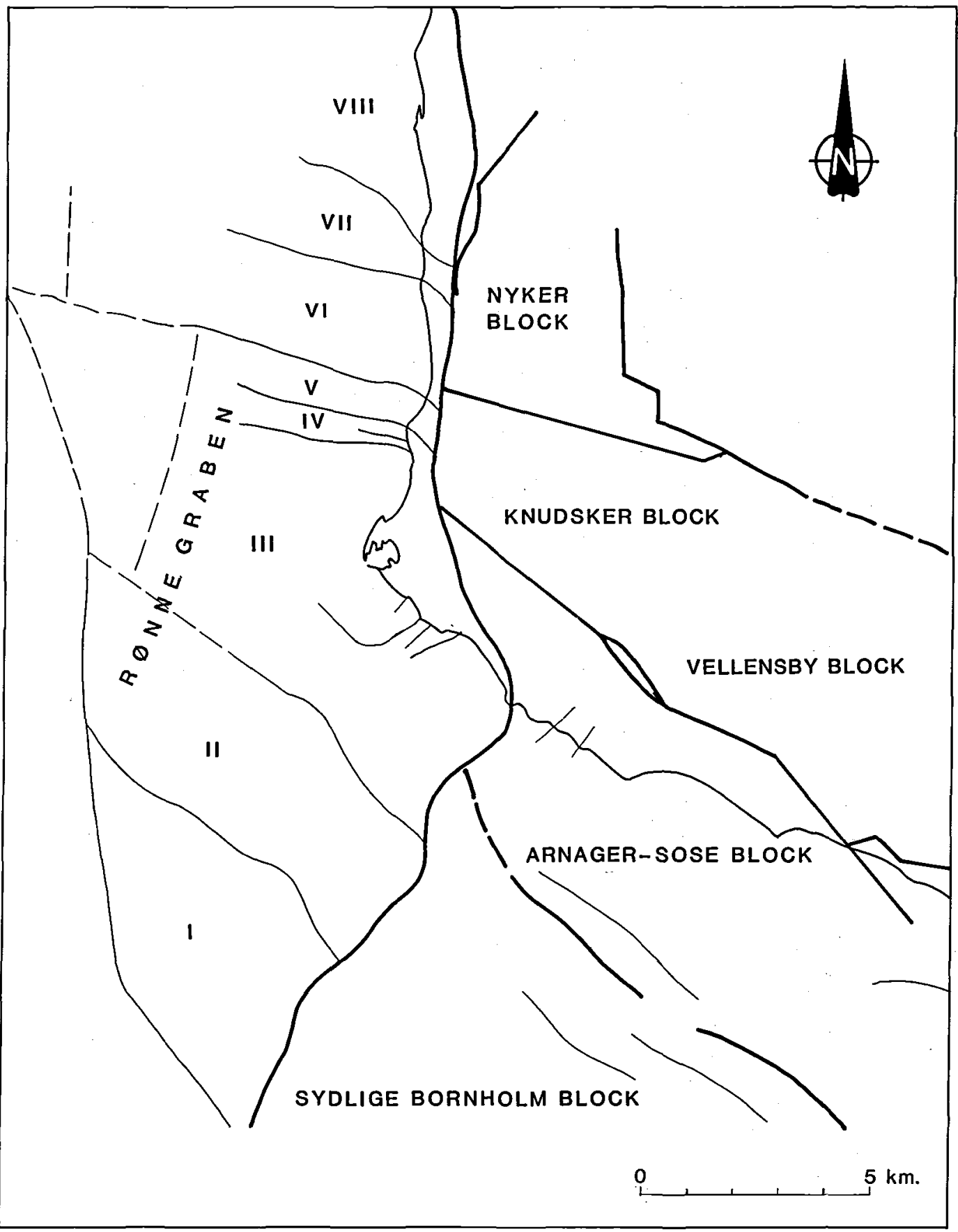

Fig. 4. Block units I - VIII and fault pattern in the area southwest of Bornholm.

mer of 1987 , involving a closely spaced sailing grid $(300 \mathrm{~m} \times 1 \mathrm{~km})$ taking echo soundings, pinger (subbottom profiles), boomer and sidescan sonar records (fig. 3b). Air gun determinations and subbottom profiles were carried out on a wider net $(3 \mathrm{~km} \times 3 \mathrm{~km})$ (fig. $3 \mathrm{c})$. These investigations, together with sampling, formed the basis for the detailed mapping (Jensen, 1988a; Jensen, 1988b).

The air gun data was used to provide a general 


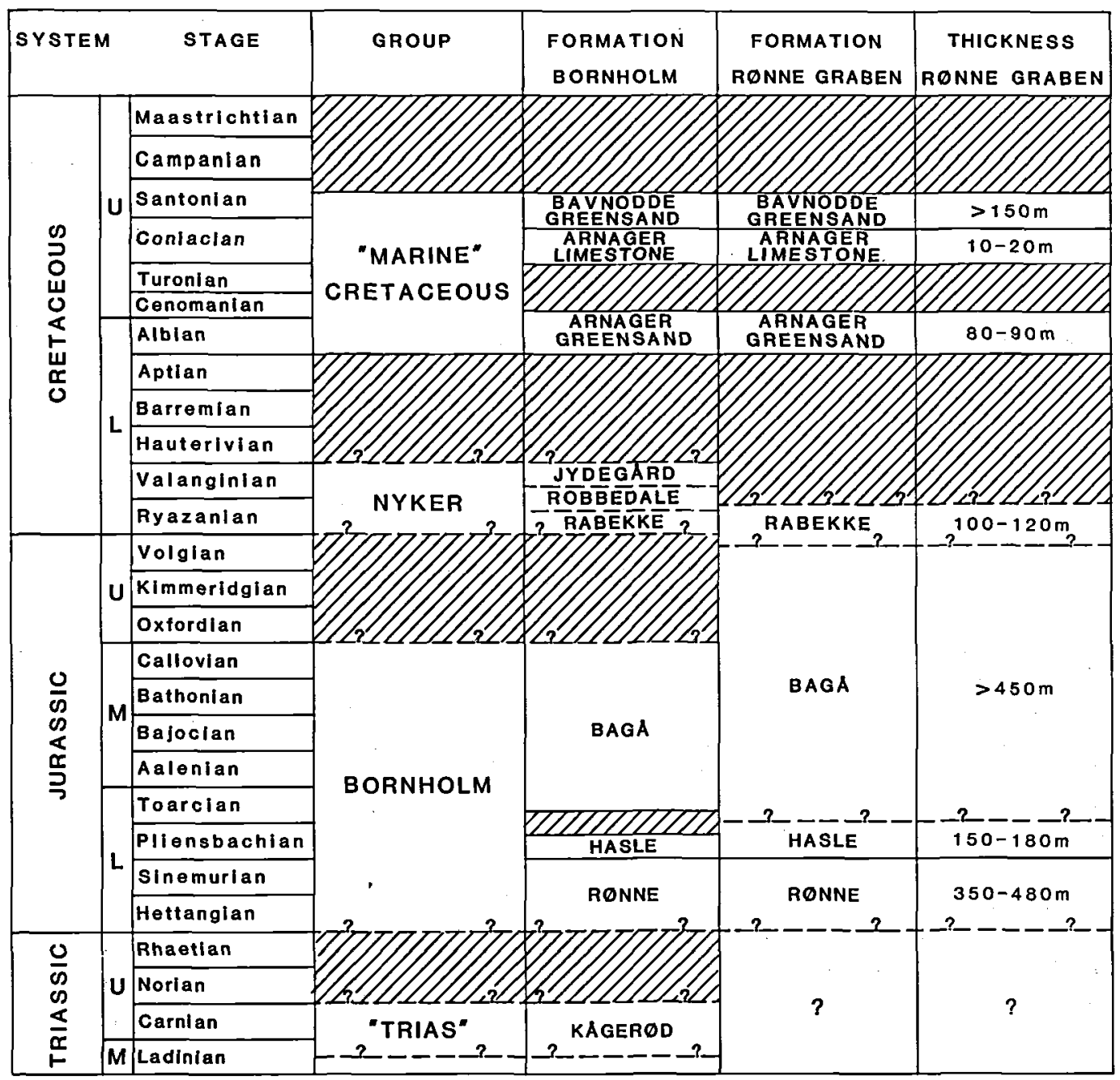

Fig. 5. Mesozoic stratigraphy of Bornholm and the north-eastern part of the Rønne Graben.

interpretation of faults and the orientation of bedding down to a maximum depth of $100 \mathrm{~m}$ (fig. 11). Boomer- and side scan sonar data show a characteristic pattern of reflectors (seismic facies) which allow the identification of seismostratigraphic units. These units have been correlated from one seismic record to the next, allowing detailed mapping of the units.

The seismostratigraphic units reflect characteristic lithologies which, when correlated with known lithostratigraphic units on land, resulted in the construction of the detailed geological map of the area (Jensen, 1988a).

\section{Mesozoic deposits in the Rønne Graben}

The Mesozoic deposits in the Nyker-, Knudsker-, Vellensby-, Arnager-Sose- and South Bornholm Blocks (fig. 4) have been described in detail by Gry (1960, 1969), Gravesen et al. (1982) and Hamann (1987b).

This description therefore concentrates on the northeastern part of the Rønne Graben area. The mapping showed that the structure here was different from that described in earlier publications. This can clearly be seen in map 1 which has been compiled using the new data presented here together with existing maps of Mesozoic deposits 


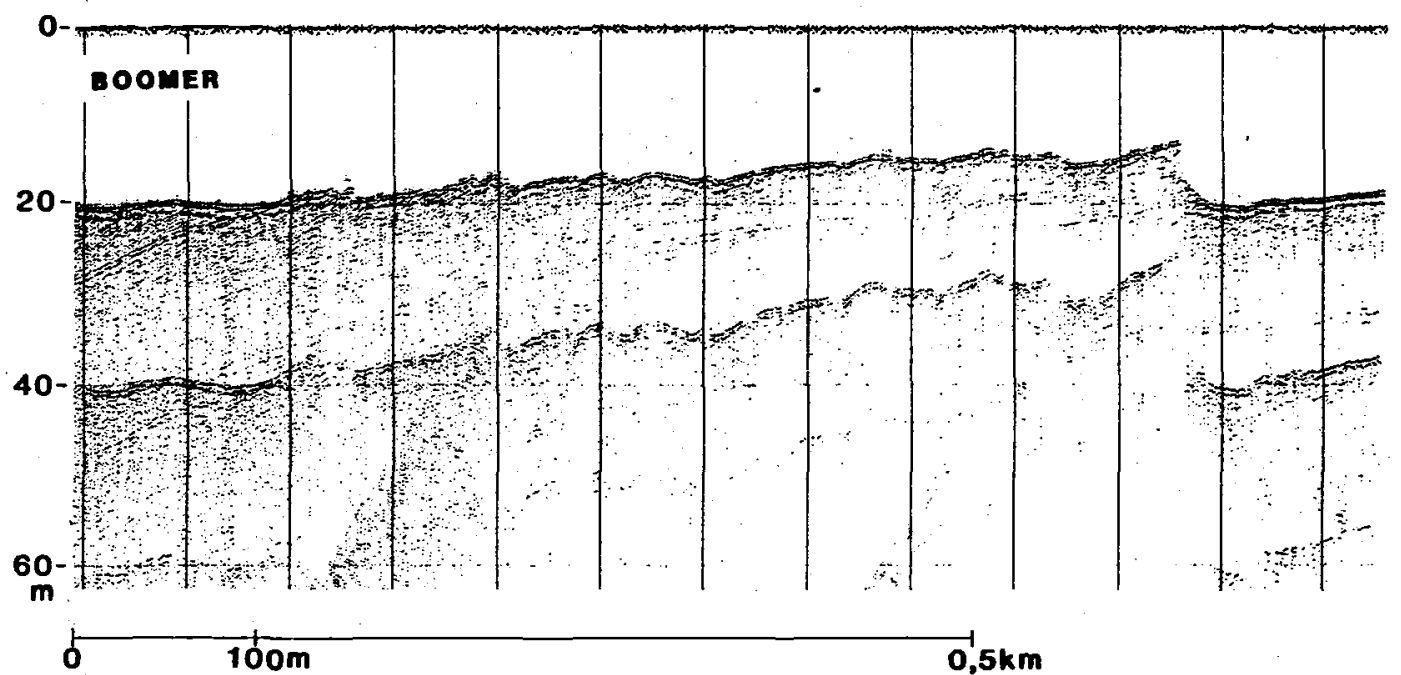

Fig. 6. Seismic reflection pattern (Boomer) of the Rønne Formation.

on land (Gry, 1960, 1969) and at sea (Vejbæk, 1985; Hamann, 1987a).

The Rønne Graben consists of several blocks (fig. 4; blocks I to VIII) containing outcropping tectonised Mesozoic deposits belonging to the Bornholm Group and parts of the Nyker Group and the (informal) Marine Cretaceous Group (fig. 5 and Map 1).

An en échelon pattern of reverse faults with a northwest-southeast orientation has resulted in a large degree of repetition from block to block (Map 1).

\section{The Rønne Formation}

The oldest Mesozoic deposits exposed on the sea floor in the area of the Rønne Graben belong to the Rønne Formation (fig. 5), occurring in blocks III and VI (fig. 4 and Map 1).

The characteristic seismic facies consists of a pattern of many closely spaced weak reflectors in a generally massive - appearing reflection pattern containing a few good reflectors (Jensen, 1988a).

Sampling and diving investigations reveal that the seismic picture can be related to the lithological development. The area with closely spaced, weak reflectors and the massive reflector pattern is identified with cross-bedded and massive sand deposits. Where localy cemented, they form marked topographical features on the sea floor (fig. 6).

The strong reflectors are believed to represent clay ironstone beds, massive beds of clay, and heterolithic units.

The lithological facies development of these deposits, together with their areal location (Map 1) suggest that they belong to the Galgeløkke Member of the Rønne Formation which has been interpreted as representing a tidal deposit (Gravesen et al. 1982, fig. 15).

The base of the Rønne Formation has not been observed since the seismic data only shows the uppermost ca. $125-150 \mathrm{~m}$ of the formation (the Galgeløkke Member) which is estimated to have a thickness of $350-480 \mathrm{~m}$ (Gry, 1960, 1969; Hamann, 1987b).

The upper boundary with the Hasle Formation is marked by a transition from sandy, clayey and carbonaceous sediments to limonite-cemented, micaceous fine sand and clay ironstone beds. The seismic data suggest that the boundary is concordant.

\section{Hasle Formation}

The Hasle Formation is exposed on the sea floor in blocks III, IV, V, VI and VIII (fig. 4 and Map 1) and is continuous from the blocks to onshore exposures.

The seismic reflection pattern consists of strong, parallel reflectors with a constant spacing of 2-5 $\mathrm{m}$ (fig. 7). These reflectors form ridges on the seafloor but the ridges are often camouflaged by accumulations of pebbles. 


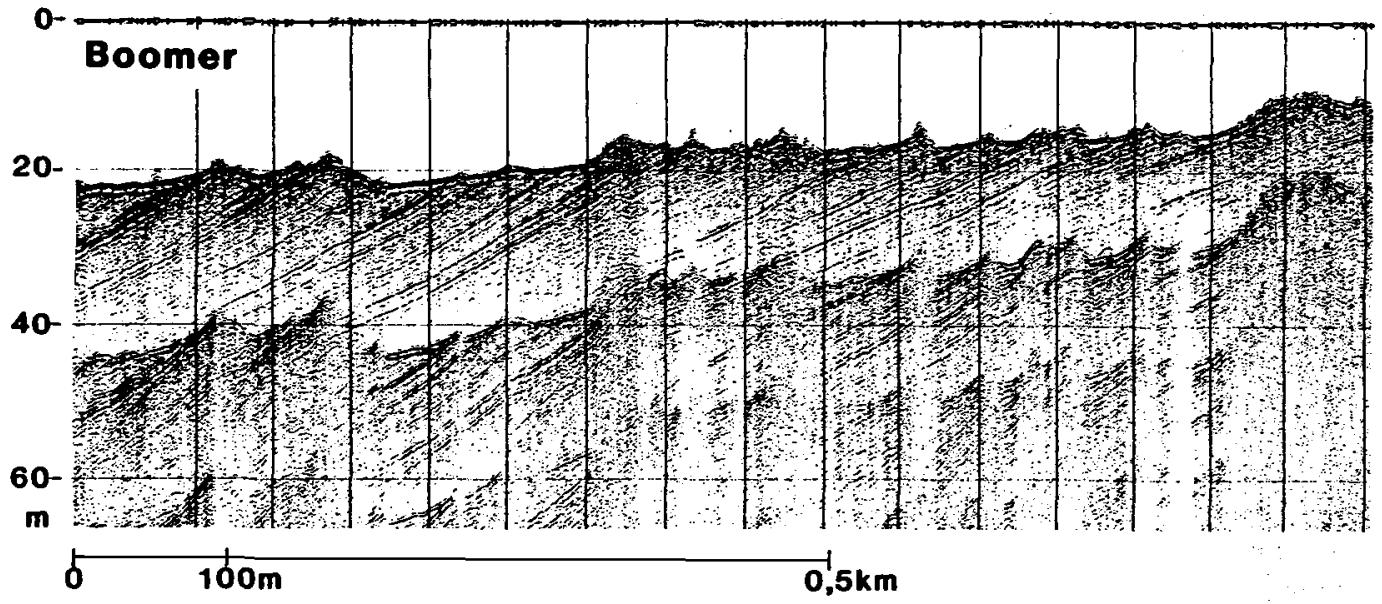

Fig. 7. Seismic reflection pattern (Boomer) of the Hasle Formation.

The reflection pattern corresponds to alternating beds of fine grained, muscovite-bearing cemented sand and clay ironstone; the clay ironstone beds are responsible for the strong reflections.

Sedimentological studies of eqquivalent deposits on land (Surlyk \& Noe-Nygaard, 1986) have demonstrated that they represent marine coastal deposits which, apart from the uppermost part of the formation, are limonitized with a redbrown colour.

In the area of investigations the Hasle Formation is overlain by the Bagå Formation. The boundary is seismically concordant but diffuse because of only minor lithological differences between the two formations at the boundary. Sedimentological studies in a coastal outcrop at Korsodde (Hamann, 1987b) confirms the seismic observations indicating continuous sedimentation. Lithologically the boundary is defined by the first occurence of thick clay units above fine grained micaceous sand.

The exact location of the upper boundary is thus uncertain and consequently the thickness of the Hasle formation is estimated to be between $150-180 \mathrm{~m}$.

\section{Upper Zone Lower Zone}

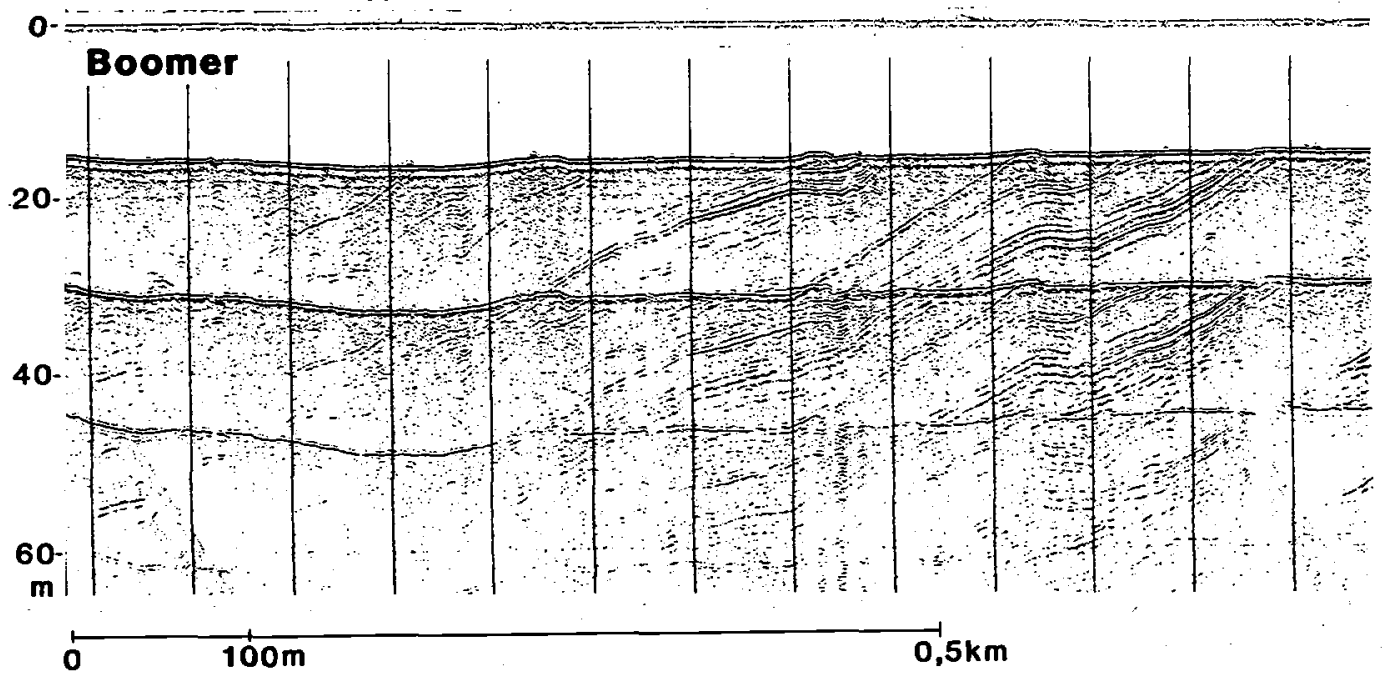

Fig. 8. Seismic reflection pattern (Boomer) of the Bagå Formation. The boundary is shown between the lower zone consisting of closely spaced reflectors and the upper zone with a generally diffuse reflection pattern. 


\section{Bagå Formation}

The most extensiv formation in the area studied is the Bagå Formation. It is present in all the blocks I-VIII (fig. 4) and in addition it has the widest areal extent (Map 1).

The seismic data allow a subdivision of the formation into a lower and an upper unit.

The lower unit has a reflection pattern (fig. 8) consisting of zones with parallel, closely spaced reflectors which often produce ridges on the sea floor. These zones alternate with zones showing a diffuse pattern. The thickness of the individual zones varies from a few metres to $15-20 \mathrm{~m}$.

The upper unit produces a dominantly diffuse reflector pattern (fig. 8) with a few very strong reflectors.

Offshore the lithology of the lower unit consists of alternating layers of sand, clay and coal. On land, similar layers are often developed as cyclic fining-upward sequences (3-5 m thick) consisting of silt or clay (sometimes heterolithic) overlain by coal-bearing clay, sometimes terminated by a root horizon and a coal layer (Hoelstad, 1985). This pattern is interrupted by sand beds up to $5-10 \mathrm{~m}$ thick. This lithological development has been interpreted to represent deltaic deposits or flood plain deposits on a coastal delta plain (Gravesen et al., 1982; Hoelstad, 1985).

The seismic and lithological features are consistent since the clayrich, coal-bearing sequences correspond to the seismic zones with the closely spaced reflectors, whereas the sandy zones produce the diffuse seismic reflection patterns (Jensen, 1988a).

The upper unit of the Baga Formation does not outcrop on land and it can therefore only be interpreted on the basis of the marine geological investigations.

The diffuse reflector pattern, supplemented by sampling and suction dredging in the area, show that the deposits consist mainly of sand. The depositional environment for these sandy sediments may have been fluviatile with continuous progradation of the delta sequence developed in the lower part of the Bagå Formation.

Studies on Bornholm (Gry, 1960) imply that the formation has a thickness of more than $270 \mathrm{~m}$ but the marine geological studies show that it is more than $450 \mathrm{~m}$ thick in the Rønne Graben area.
The boundary between the Bagå Formation and the Rabekke Formation is difficult to locate precisely since the lower part of the Rabekke Formation also consists of sandy deposits.

\section{The Rabekke Formation}

The Rabekke Formation is the oldest unit of the Lower Cretaceous (fig. 5) and in the Rønne Graben it is the only representative of the Nyker Group; it is present in blocks I, II and VII (fig. 4 and Map 1):

The formation can be subdivided into a lower and an upper unit which have very distinctive seismic reflection patterns.

The lower unit has a reflection pattern very similar to that in the upper Bagå Formation although the Rabekke Formation has local, closely spaced weak reflectors in a generally diffuse reflection pattern (figs. 9a \& 9b).

Equivalent deposits on land have been described as a separate member Homandshald Member; (Gravesen et al., 1982) which has been interpreted to represent a fluviatile deposit.

The upper unit can be characterized seismically by the presence of a series of 8-12 strong, parallel reflectors which form ridges on the sea floor (figs. $9 \mathrm{a} \& 9 \mathrm{~b}$ ) with a constant spacing of $20-30 \mathrm{~m}$. Weak reflectors which often occur between these are likewise parallel.

The upper unit of the Rabekke Formation is a most impressive seismic unit which can be traced across many seismic lines without significantly changing character. The seismic pattern is due to kaolinitic clay and coal-bearing clay horizons interbedded with fine-grained sand units. Equivalent deposits on land have been interpreted as lacustrine to marginal marine deposits (the Skyttegård Member; Gravesen et al., 1982).

The thickness of the Rabekke Formation on Bornholm has been estimated to be $45-105 \mathrm{~m}$ (Gravesen et al. 1982). In the Rønne Graben it is estimated to be $100-120 \mathrm{~m}$ thick, with some uncertainty because of the difficulty of locating the boundary between the Bagå and Rabekke Formations.

The top of the Rabekke Formation is clearly seen as a powerful reflector on the boomer record where the reflector can be followed below the first multiple (fig. 9a). This is correlated with a major conglomerate bed that occures just above 

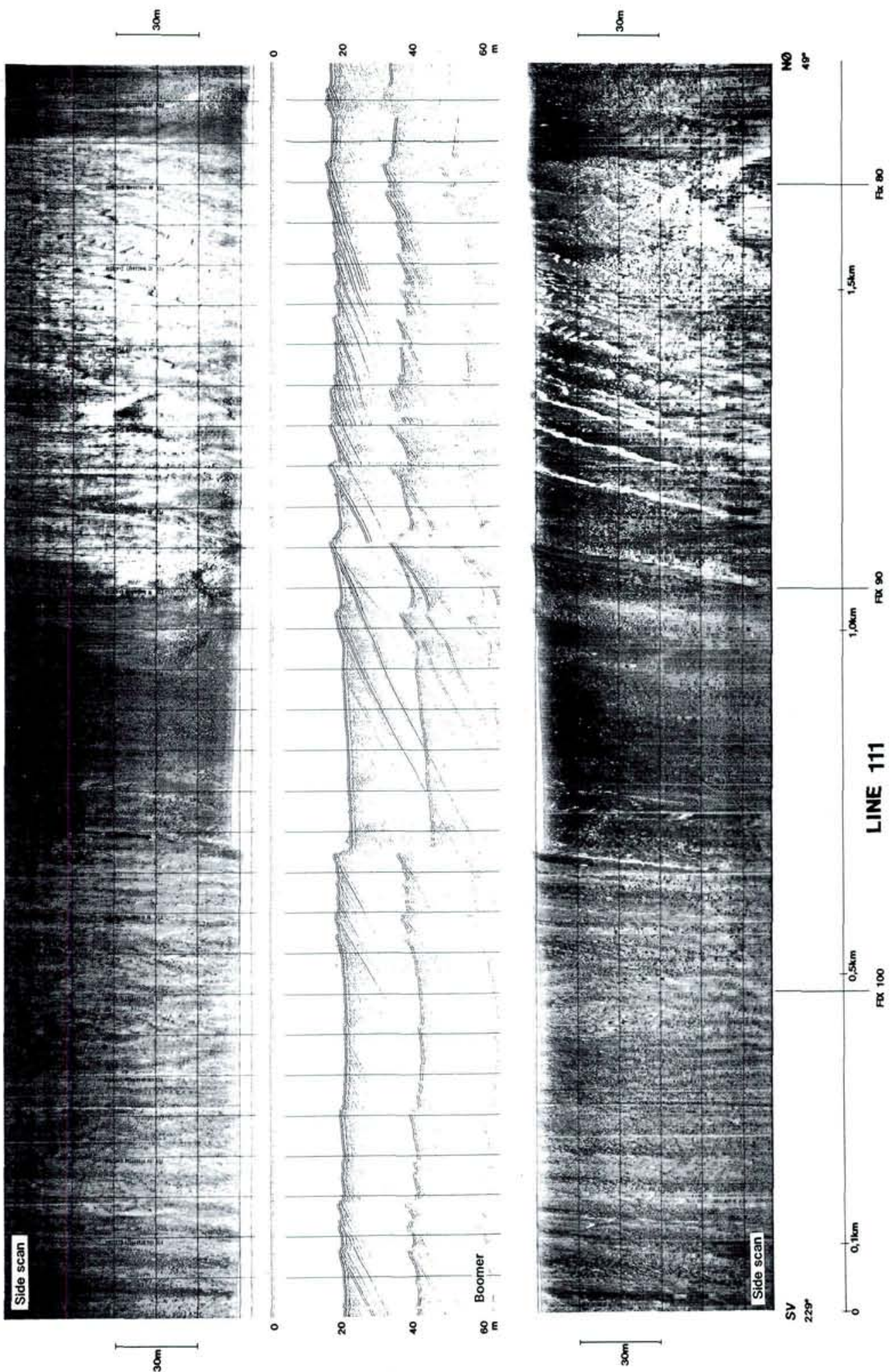

Fig. 9. Seismic line 111. See fig. 3b. for location of the sailing line,

Fig. 9a. Seismic reflection pattern line 111 (Boomer and side scan sonar). 


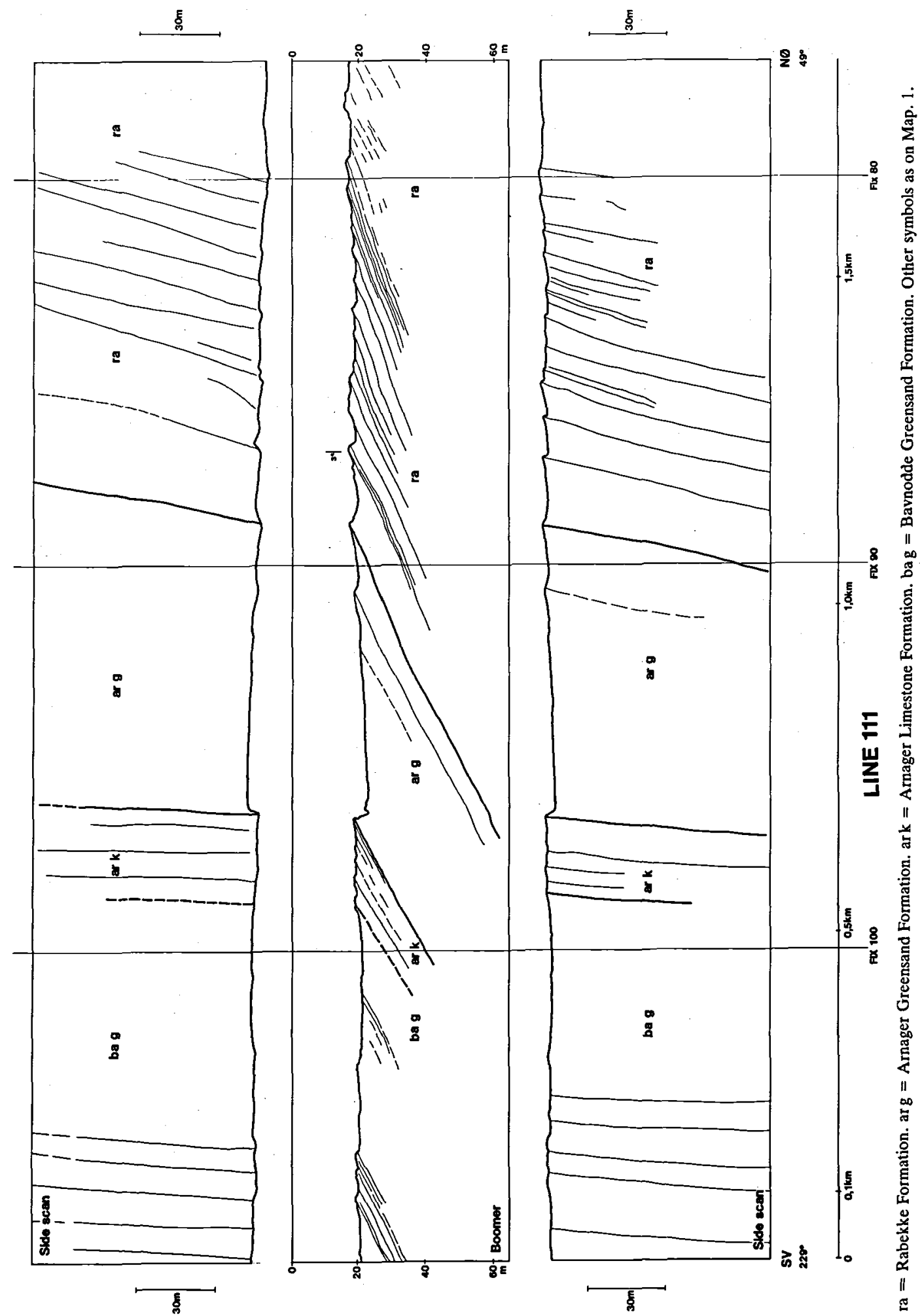

Fig. 9b. Interpretation of seismic reflection pattern line 111. 
the base of the Arnager Greensand Formation, onshore Bornholm.

This well consolidated phosphorite conglomerate forms a feature on the sea floor, and on the seismic sections it forms a well-defined dipping layer which sometimes produces a seismic diffraction pattern. This can be seen in fig. 9a where diffractions are present as branches below the reflector.

The presence of this phosphorite conglomerate indicates that there was a hiatus between the Rabekke Formation and the overlying Arnager Greensand Formation (Kennedy et al., 1982), but the seismic results do not suggest the presence of an angular discordance.

\section{The Robbedale- and Jydegård Formations}

These formations form extensive coastal segments on the Arnager-Sose Block and the Nyker Block (fig. 4) (Gravesen et al., 1982) but they are not present in the Rønne Graben where the Rabekke Formation is in contact with the Arnager Greensand Formation (fig. 5 and Map 1).

Their absence in the Rønne Graben is consistent with the model proposed by Noe-Nygaard \& Surlyk (1988), in which the position of the coastline, and hence the coastal facies (Robbedale and Jydegård Formations) was tectonically anchored.

\section{The Arnager Greensand Formation}

The Arnager Greensand Formation, which is the oldest unit in the Marine Cretaceous Group (fig. 5 ), is present in blocks I and II in the Rønne Graben (fig. 4 and Map 1).

As mentioned above, its seismic reflection pattern is dominated by the diffraction pattern generated by the near base conglomerate. In addition to this there are a few strong reflectors in the lower part of the formation, while the remaining part shows a rather diffuse reflection pattern (figs. 9a \& 9b).

From submarine sampling it appears that the lithological features which give rise to these strong reflectors, in addition to the phosphorite conglomerate, are zones of cemented glauconitebearing quartz sandstone with phosphorite nodules.

The Arnager Greensand Formation has been interpreted to represent coastal marine deposits
(Kennedy et al., 1980) which have a thickness of 80-90 $\mathrm{m}$ in the Rønne Graben (Hamann, 1987b).

The upper boundary of the formation with the Arnager Limestone Formation does not appear to be discordant on the seismic record, but investigations on Bornholm show that it is an erosion surface (Noe-Nygaard \& Surlyk, 1985).

\section{The Arnager Limestone Formation}

This formation, belonging to the Marine Cretaceous Group (fig. 5), is exposed in blocks I and II in the Rønne Graben (fig. 4 and Map 1).

The presence of siliceous limestone in this formation results in a readily recognizable seismic reflection pattern; it consists of a series of closely spaced, strong reflectors which together form a "plateau"-like feature in the sea floor (figs. 9a \& 9b).

The lithology of the Arnager Limestone has been studied in detail along the coastal profile in Arnager Bay (Noe-Nygaard \& Surlyk, 1985). This study showed that the unit consists of a hard, siliceous limestone (55-65\% carbonate) with a sparse macrofauna.

The basal part contains a thin conglomerate, while the rest of the formation consists of an overlapping reef complex formed by siliceous sponges that served as traps for fine grained sedimentary particles (Noe- Nygaard \& Surlyk, 1985).

The Arnager Limestone, which has a thickness of $10-20 \mathrm{~m}$, has a concordant upper boundary with the Bavnodde Greensand Formation. The greensand rests on an uneven nodular surface of Arnager Limestone (Hamann, 1987b).

\section{The Bavnodde Greensand Formation}

The Bavnodde Greensand Formation is the youngest Mesozoic formation exposed in the Bornholm region; in the Rønne Graben it is present in blocks I and II (fig. 4 and Map 1).

The seismic reflection pattern is similar to that produced by the Arnager Greensand Formation, with a generally diffuse pattern interrupted by a few strong reflectors (figs. 9a \& 9b).

Only the lowest part of the Bavnodde Greensand outcrops in the detailed mapped area of the Rønne Graben, but previous investigations (Hamann, 1987b) show that the upper part consists 
entirely of weak reflectors. The lithology represented by the strong reflectors consists of cemented glauconitic quartz sandstone (and occasional conglomerates) which form ridges on the sea floor; unconsolidated glauconitic sand gives rise to the weak reflectors.

Brüsch (1984) has interpreted the formation as representing shallow water shelf sediments, deposited in water depth of $40-120 \mathrm{~m}$.

Only the lowest part of the Bavnodde Greensand Formation is exposed in the Rønne Graben, with a thickness of about $150 \mathrm{~m}$. The whole formation may be as thick as $800 \mathrm{~m}$ (Hamann, 1987b).

\section{The geological structure in the Rønne Graben area}

The main structural relationships in the Bornholm area have been described previously on the basis of deep seismic studies (Vejbak, 1985; Liboriussen et al., 1987) and general shallow seismic investigations (Hamann, 1987b). The shallow seismic studies presented here allow more detailed description of the structure in the Rønne Graben area, especially concerning the late Cretaceous - early Tertiary period.

It is therefore possible to describe the structural style in the area as a basis for interpretation of the development of the Laramide orogenic phase.

The dominante structural feature in the area is a major roughly north-south trending reverse fault (fig. 10 and Map 1). This fault separates the Rønne Graben from the blocks to the east (the Nyker, Knudsker, Arnager-Sose and South Bornholm blocks) (fig. 4).

Reverse movement along this major fault produced anticlinal flexure folds (fig. 11) in the Rønne Graben whose axes are roughly parallel with the major fault (fig. 10).

Another structural feature of the Rønne Graben is the presence of a number of en échelon reverse faults approximately perpendicular to the main north-south reverse fault. These mutually parallel faults are spaced at intervals of about 1-4 $\mathrm{km}$ along the main north-south reverse fault. A series of flexure folds are related to these faults (figs. 10 \& 12).

The development of these two sets of flexure folds has resulted in fold interference in the vicinity of the main fault where the en échelon fold axes change their plunge directions from northwest to southeast (fig. 13).

Near the main fault the en échelon reverse faults curve towards the south, implying a lateral, northwards component of movement of the Rønne Graben Blocks (fig. 10 and Map 1). The main fault can therefore be classified as a dextral wrench fault with a reverse component.

The structural style changes from the southern to the northern part of the area in that the main fault changes direction to a more north-south trend in the vicinity of the crystalline basement on Bornholm. This is accompanied by a change in direction of the en échelon faults and a reduction in their spacing (fig. 10 and Map 1).

Furthermore, the pattern of the blockmovements varies from south to north. The southern blocks become relatively elevated towards the south (fig. 12) while the north of Rønne, graben and horst features are developed in addition to this (fig. 14).

The structural pattern illustrated by the Rønne Graben is equivalent to that developed along a strike-slip fault system formed by simple shear (Wilcox et al., 1973; Atilla \& Benjamin, 1984).

Model experiments of simple wrench tectonics carried out using clay models (Wilcox et al., 1973) show a characteristic pattern of deformation which is similar to that developed in the Rønne Graben area.

According to this model a possible strain elipsoid for wrench movements in the Rønne Graben area (fig. 15) shows that a dextral fault forms first (synthetic fault in fig. 15), equivalent to the major eastern fault of the graben structure. Further wrench movement can give rise to antithetic faults (fig. 15) which have not been observed in the area studied. A feature typical of the simple shear model which then can develop is a series of en échelon reverse faults orientated normal to the direction of maximum compression (figs. 10 \& 15), and possibly also normal faults at right angles to the direction of maximum extension.

This structural analysis implies that the eastern margin of the Rønne Graben was subjected to simple shear with wrench movement during the Laramide orogenic phase, as shown in fig. 15. The presence of anticlinal flexural folds adjacent to the main fault requires a compressive compo- 


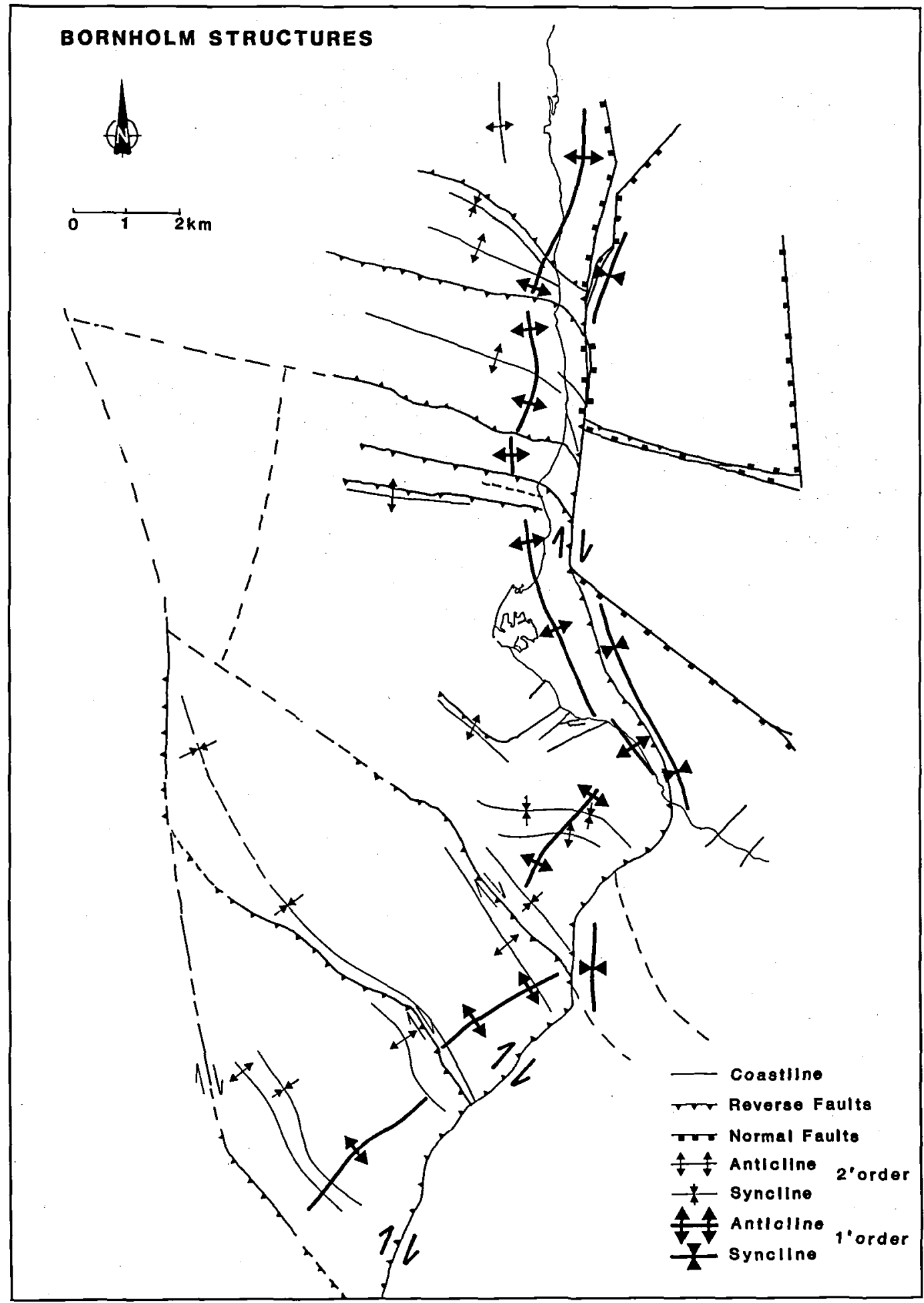

Fig. 10. Geological structure of the north-eastern part of the Rønne Graben.

The figure shows faults as well as hinge lines along the major fault (called $1^{\text {st }}$ order hinge lines) and hinge lines along the en échelon faults ( $2^{\text {nd }}$ order hinge lines). 


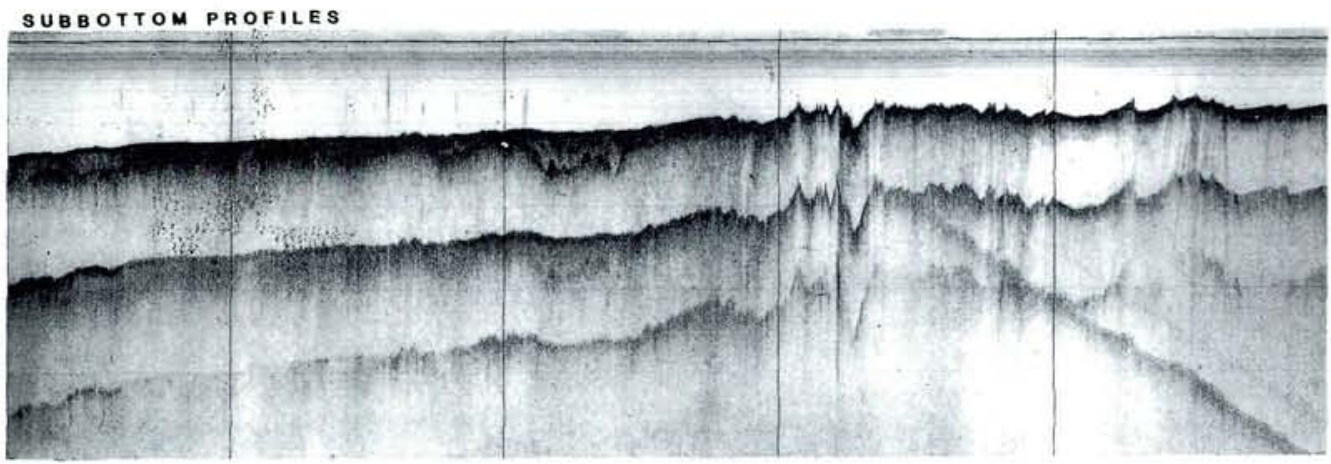

\section{AIRGUN}
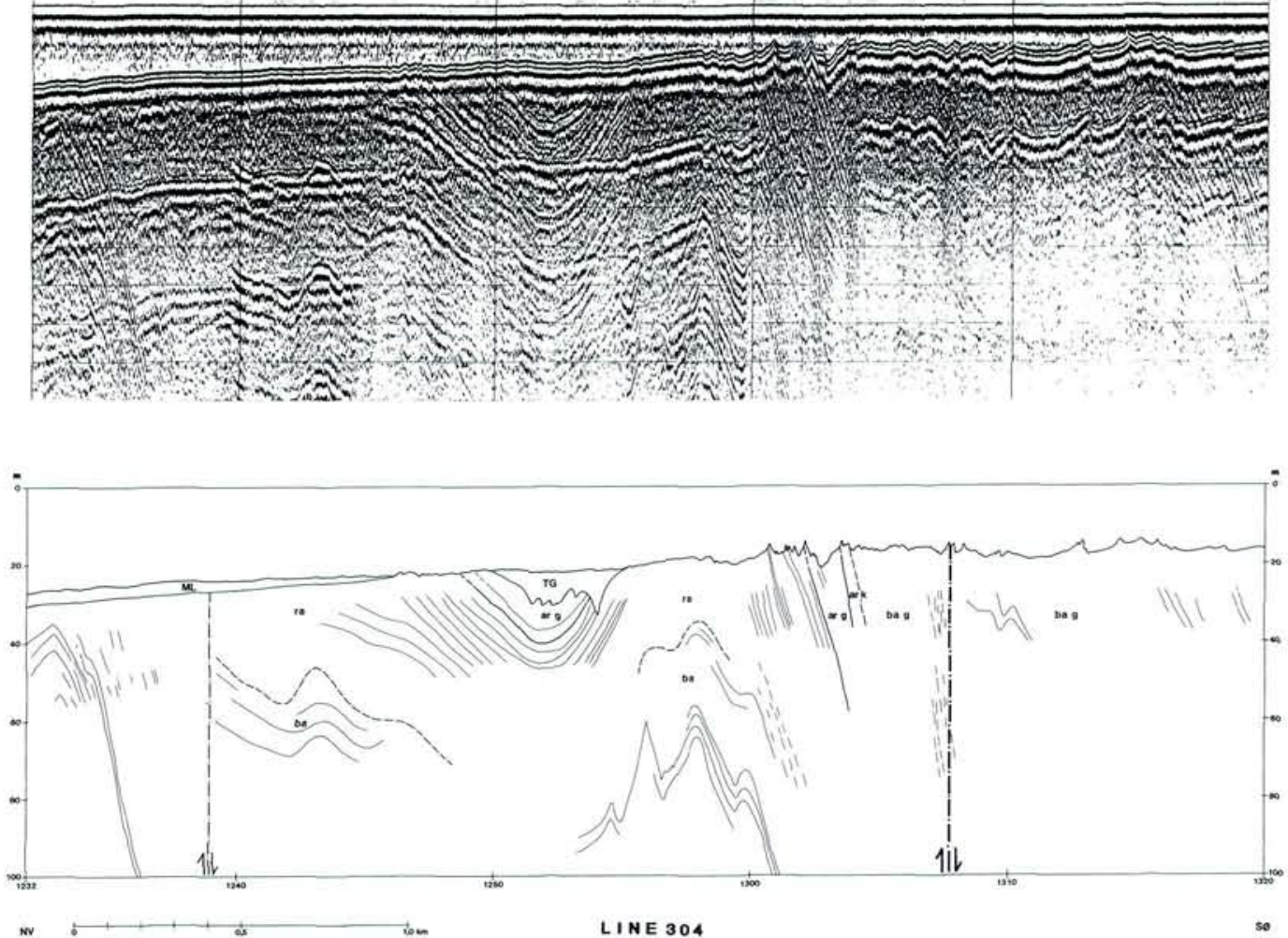

Fig. 11. Seismic line 304 (subbottom profile and air gun). See fig. 3c. for location of the sailing line.

ba $=$ Bagå Formation.

$\mathrm{ra} \quad=$ Rabekke Formation.

ar $\mathrm{g}=$ Arnager Greensand Formation.

ar $\mathrm{k}=$ Arnager Limestone Formation.

ba $\mathrm{g}=$ Bavnodde Greensand Formation.

$\mathrm{ML}=$ till clay.

$\mathrm{TG}=$ late glacial gravel.

Other symbols as on Map 1. 
SUBBOTTOM PROFILEA

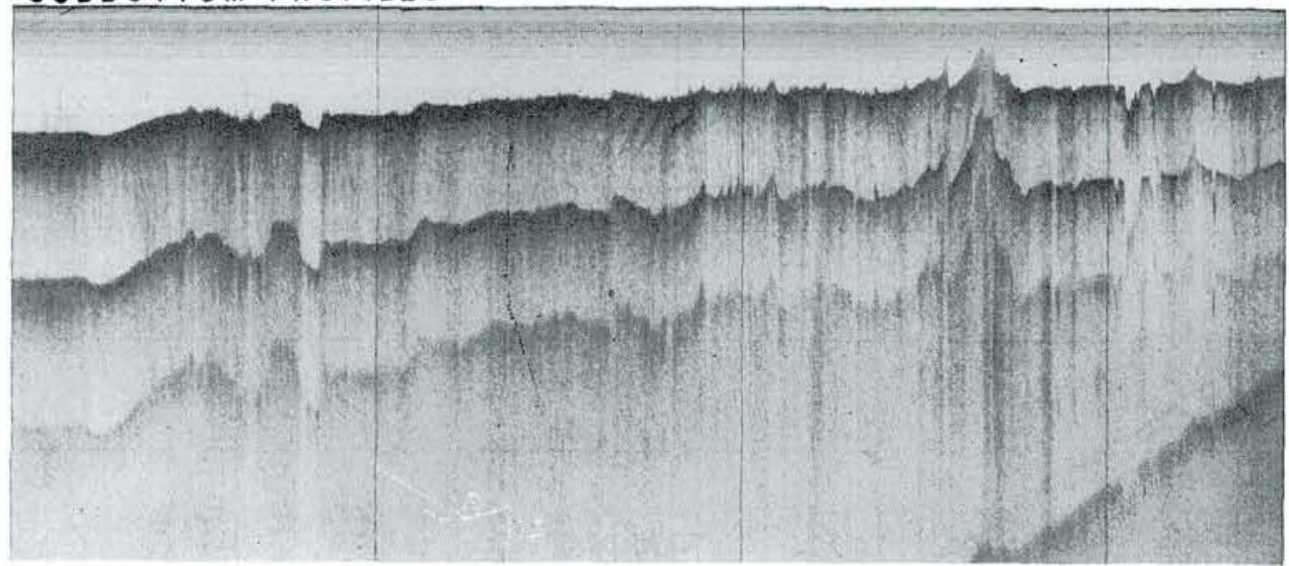

\section{AIRQUN}
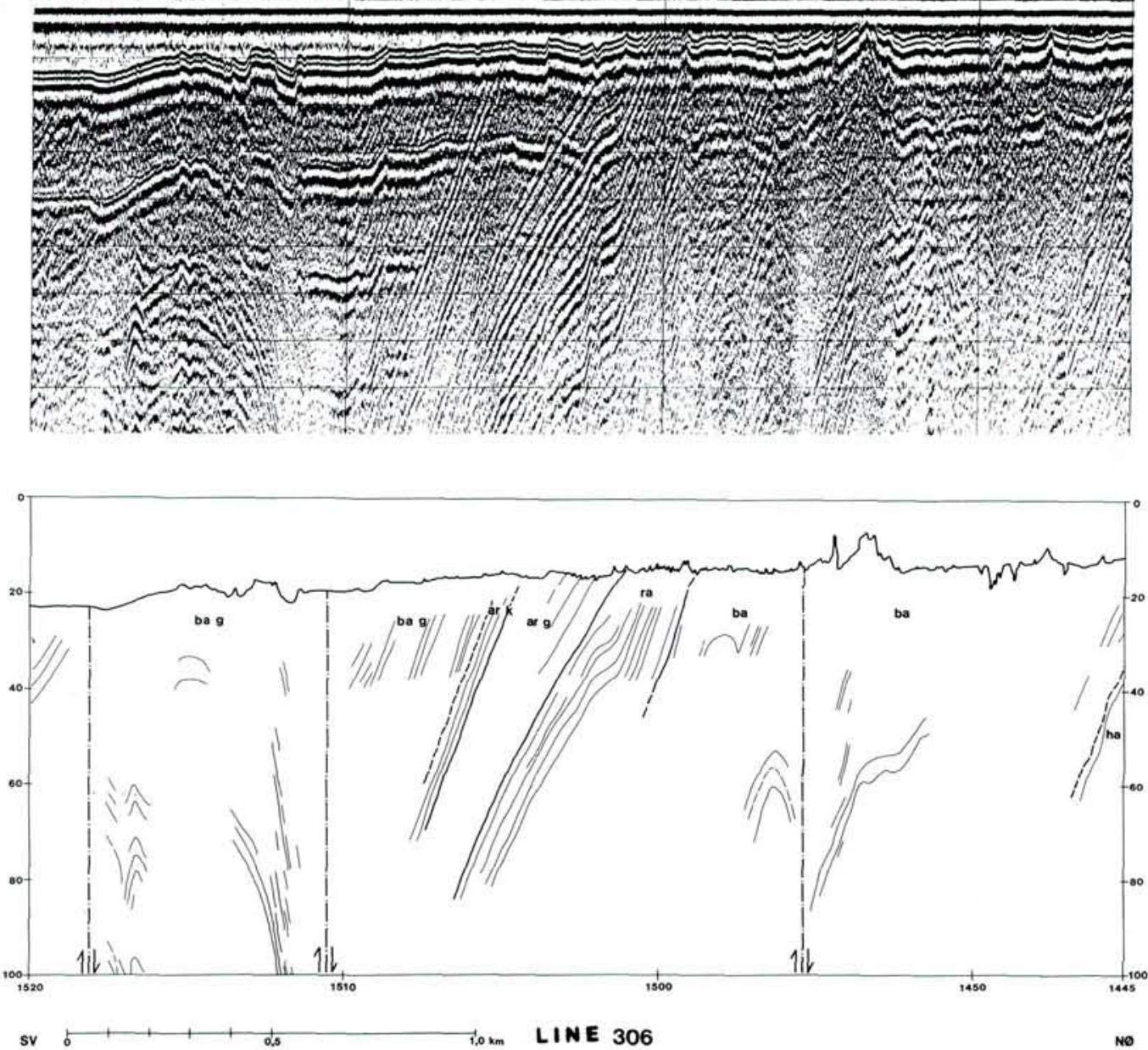

Fig. 12. Seismic line 306 (subbottom profile and air gun). See fig. 2c. for location of the sailing line.

ba = Bagă Formation.

ra $=$ Rabekke Formation.

ar $\mathrm{g}=$ Arnager Greensand Formation.

ar $\mathrm{k}=$ Arnager Limestone Formation.

ba $\mathrm{g}=$ Bavnodde Greensand Formation.

Other symbols as on Map 1. 

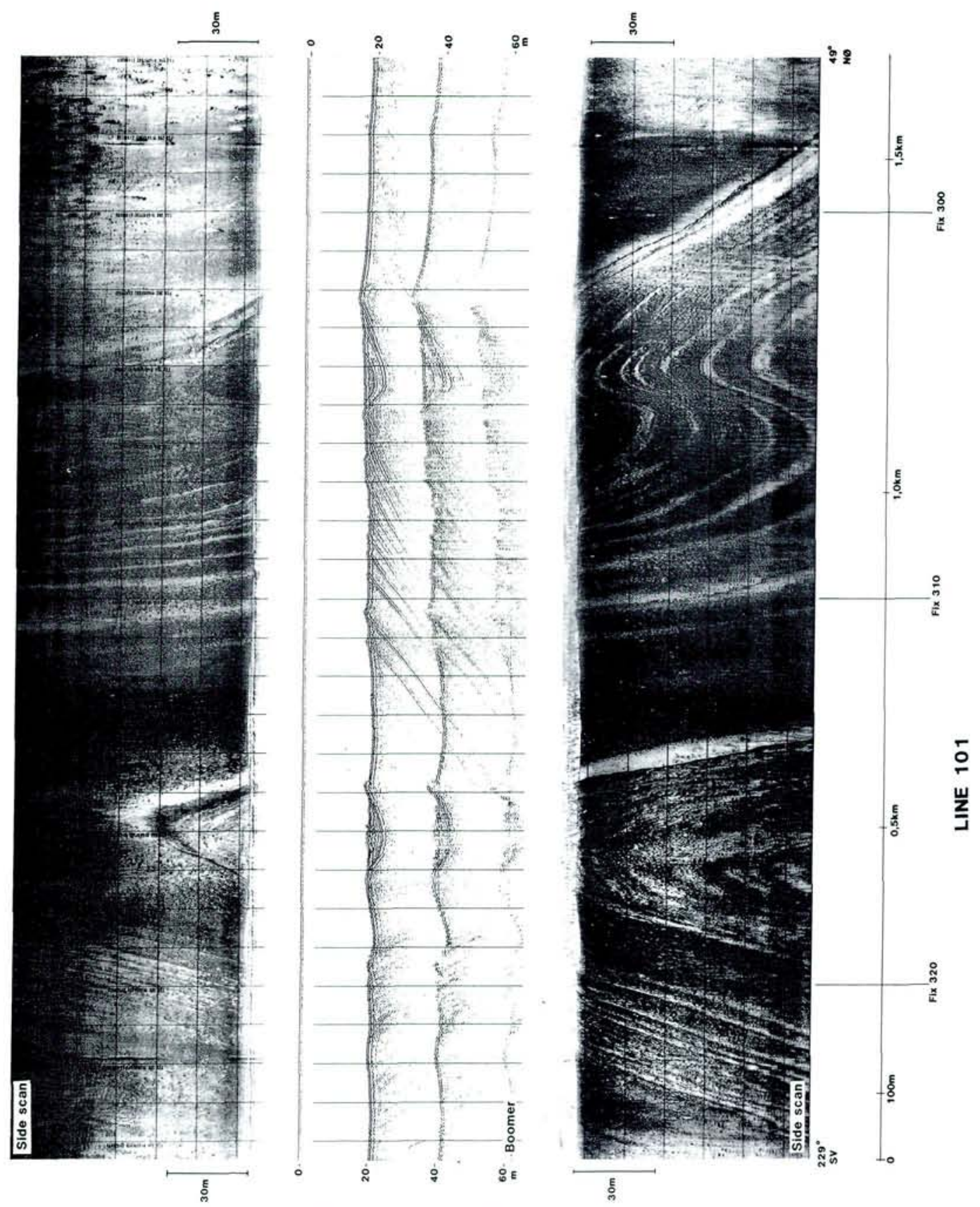

Fig. 13. Seismic line 101. See fig. 2c. for location of the sailing line.

Fig. 13a. Seismic reflection pattern line 101 (Boomer \& side scan sonar). 


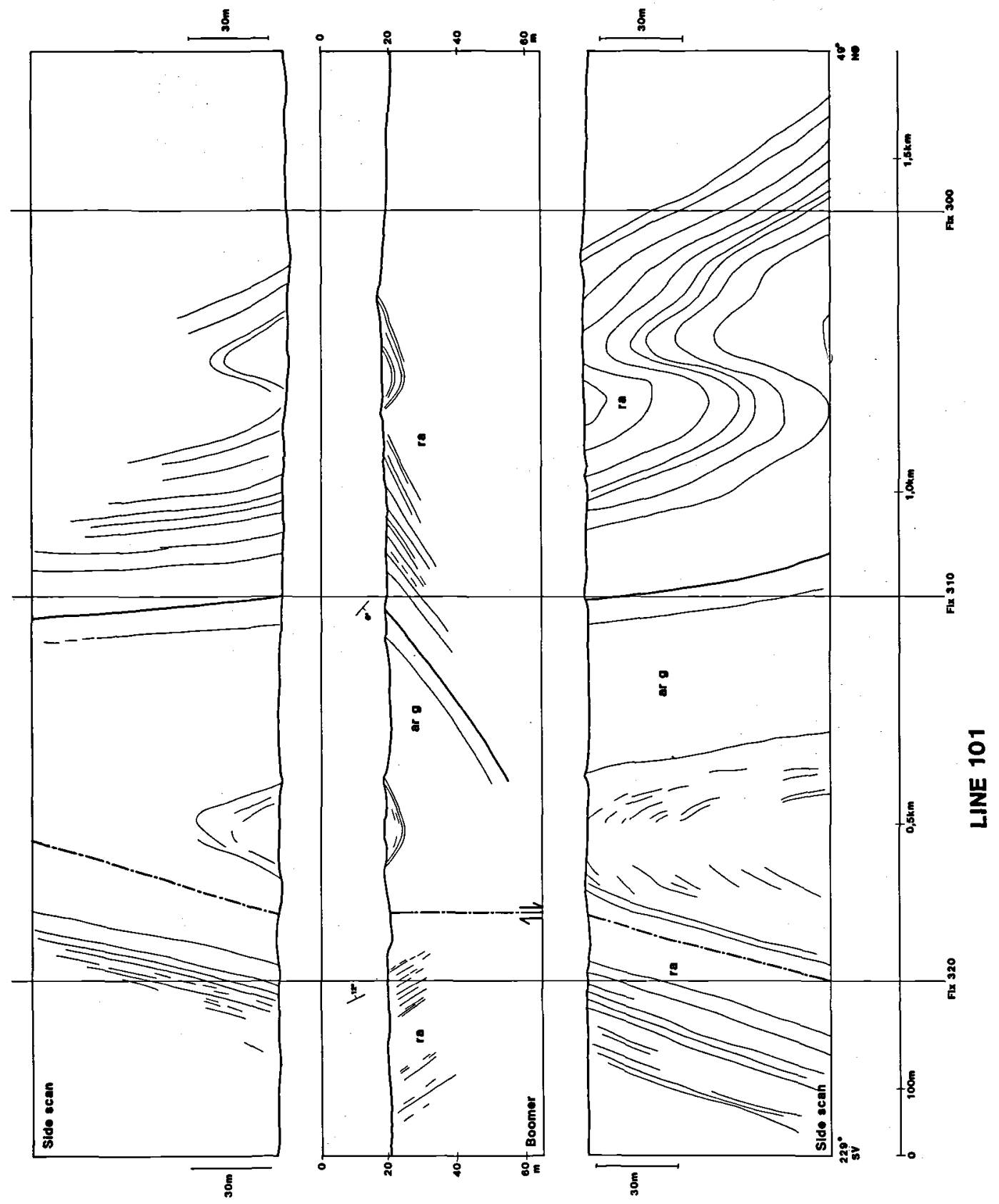

Fig. 13b. Interpretation of seismic reflection pattern line 101.

ra $=$ Rabekke Formation.

ar $\mathrm{g}=$ Arnager Greensand Formation.

Other symbols as on fig. 4 . 

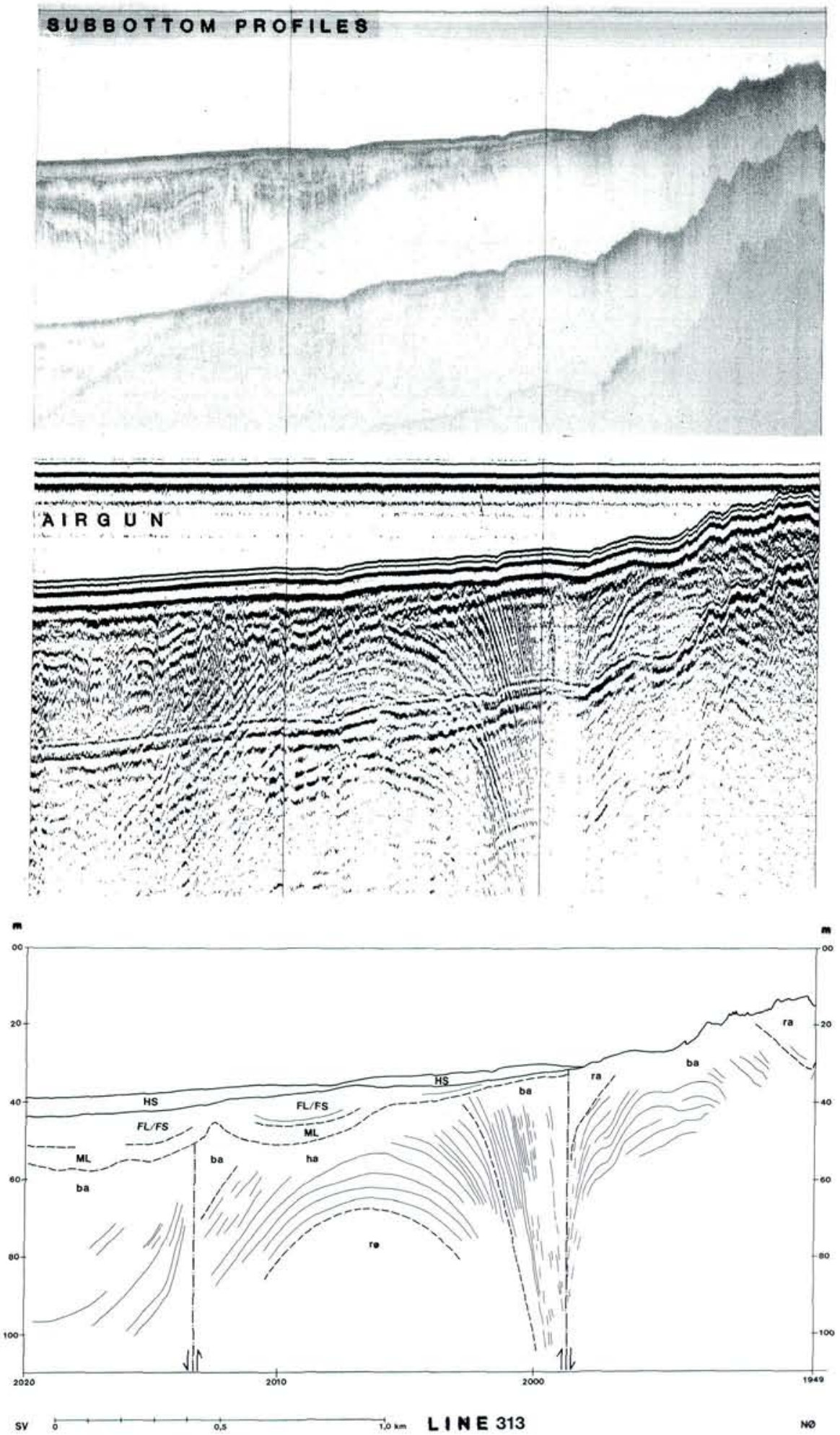

Fig. 14. Seismic line 313 (subbottom profile and air gun). See fig. 2c. for location of the sailing line.

$r \emptyset=$ Rønne Formation.

ha $=$ Hasle Formation.

ba $=$ Bagå Formation.

$\mathrm{ra}=$ Rabekke Formation.

ML $=$ till clay.

FL/FS $=$ post glacial fresh water clay \& sand.

HS $=$ post glacial marine sand.

Other symbols as on fig. 4 . 


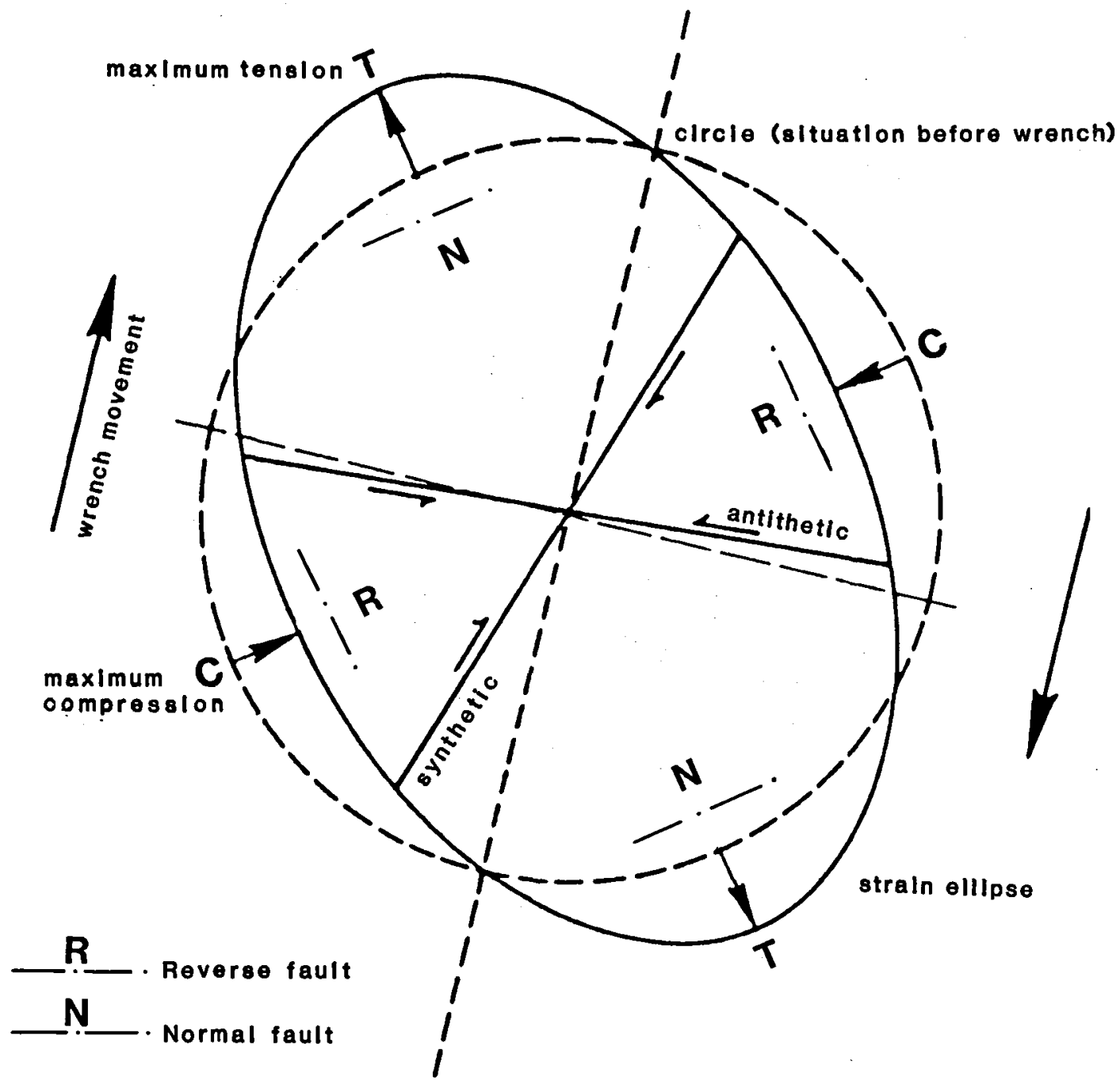

Fig. 15. Wrench movement along the eastem margin of the Rønne Graben and the resulting strain elipsoid.

nent to the fault which suggests that the system involved compressive dextral strike slip movement.

The shallow seismic data presented here show that the fault system was effective down to at least $100 \mathrm{~m}$ below sea level. However, comparison with previous deep seismic studies (Vejbæk 1985) shows that these faults can be traced at least two kilometers down into the subsurface (figs. 16a \& 16b).
The distribution of mesozoic strata in the Bornholm area

The detailed geological mapping of the Rønne Graben area (Map 1) has changed the interpretation of the distribution of Mesozoic deposits in the Bornholm area.

Earlier data (Gry, 1969; Vejbæk, 1985; Larsen 1986; Hamann, 1987a) has therefore been combined with the new information from the Rønne Graben to produce a map of Mesozoic formations at the base of the Quaternary in the Bornholm area (fig. 17).

This map shows how the Mesozoic formations 
Fig. 16. Fault pattern in the Rønne Graben. Fig. 16a. After

Vejbæk, 1985.

Fig. 16b. According to the data presented in this article.

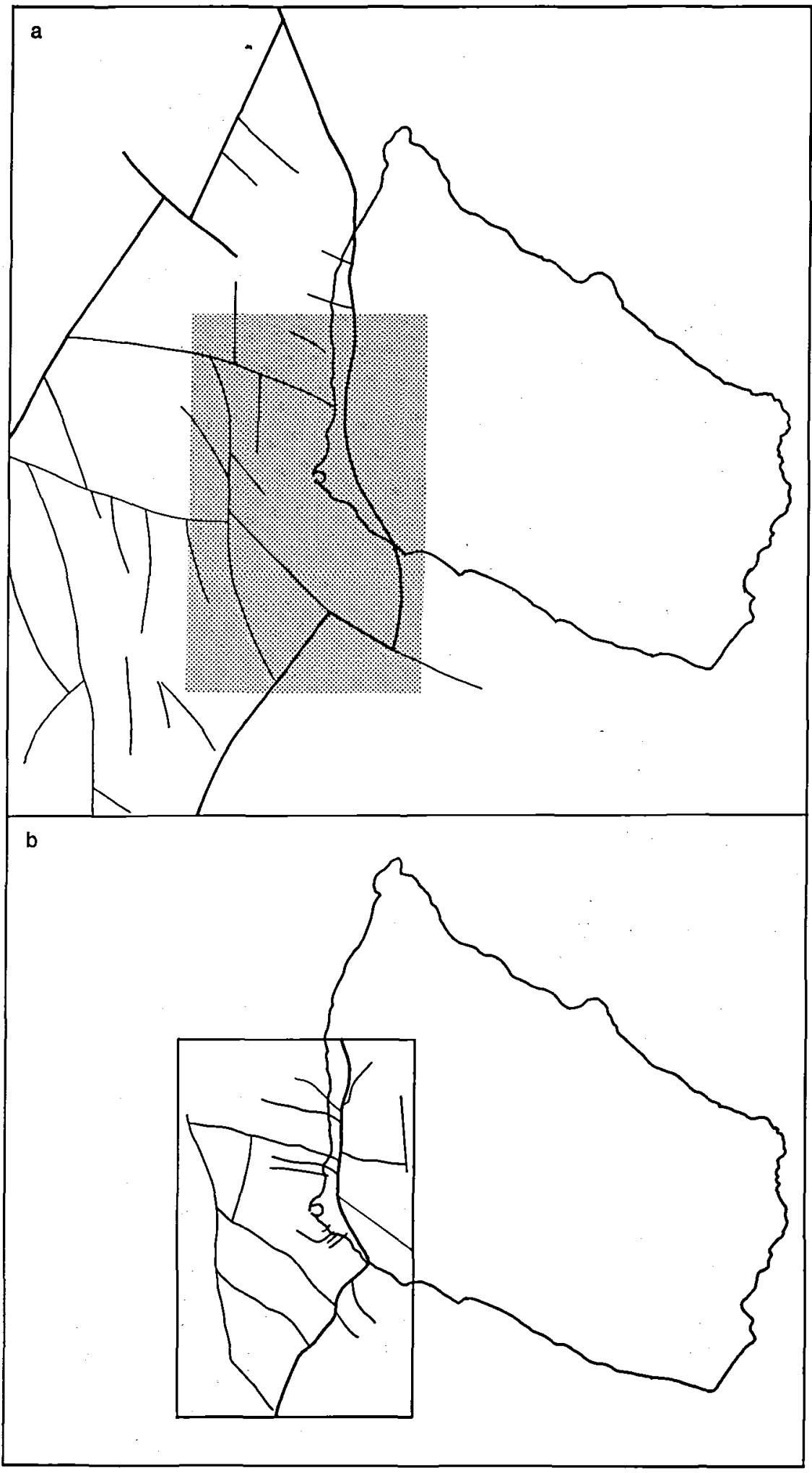



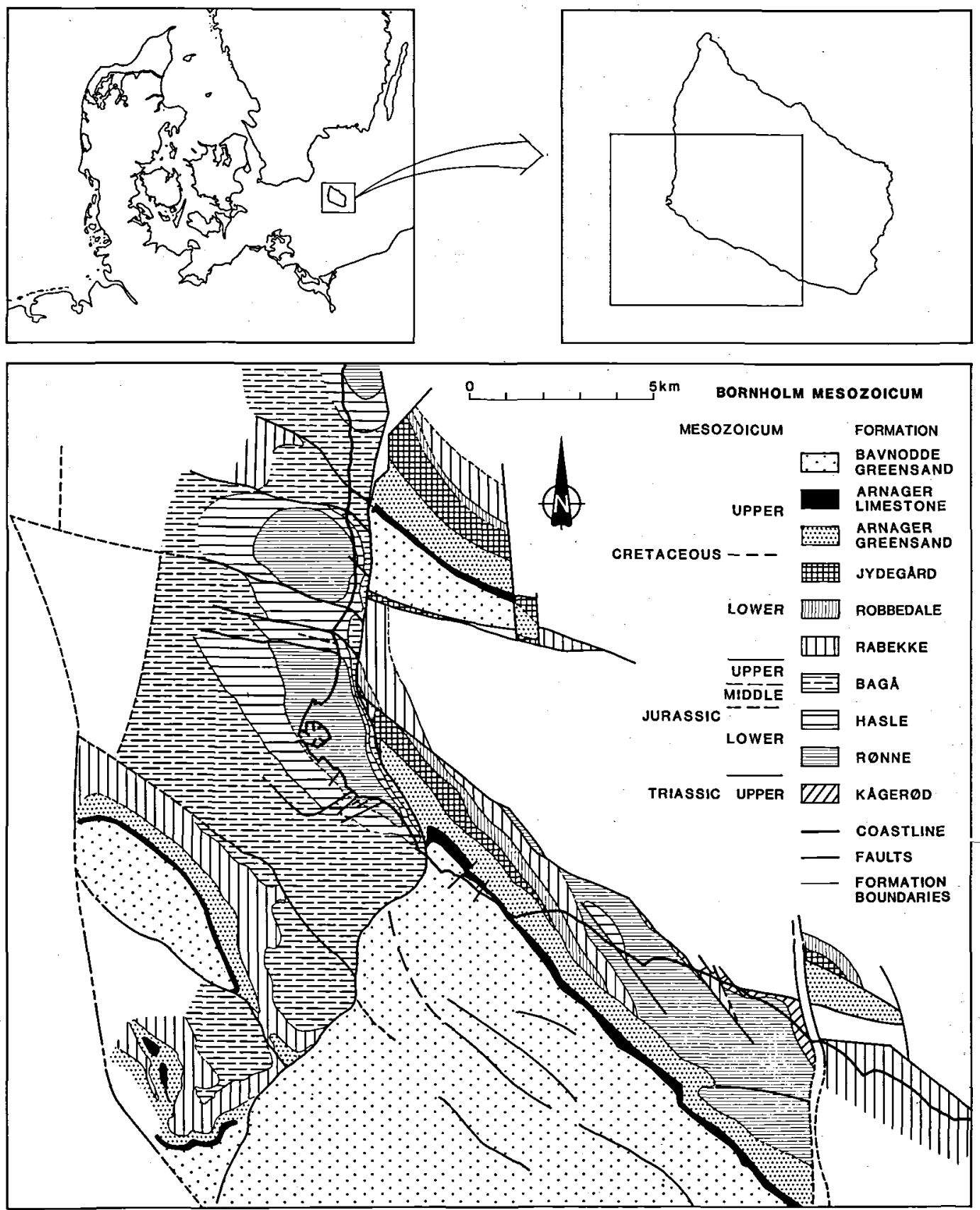

Fig. 17. The pre-Quaternary Mesozoic surface of the Bornholm area. Outside the Rønne Graben, map compilation includes data from Gry $(1960,1969$, Vejbæk (1985) and Hamann (1987a).

are distributed on the individual blocks (fig. 4). The Pre-Quaternary surface in the Rønne Graben consists of Mesozoic deposits ranging from the Rønne Formation (Lower Jurassic) to the Bavnodde Greensand Formation (Upper Creta- ceous) (fig. 5). While the Robbedale and Jydegåd Formations are developed on the Nyker, Knudsker, Vellensby and Arnager-Sose Blocks, they are absent in the Rønne Graben and on the South Bornholm Block. 


\section{Concluding Remarks}

Detailed shallow reflection seismic investigations along the eastern margin of the Rønne Graben have provided precise data which, based on characteristic reflector patterns, have been correlated with known lithostratigraphic units on land.

All of the formations which have been recognized in the area are present on Bornholm, but there appears to have been continous sedimentation in the Rønne Graben from Early Jurassic til Early Cretaceous times (fig. 5).

The transition from the Hasle to the Baga Formation (fig. 5) does not appear to represent a hiatus but a gradual transition from marine coastal deposits to deltaic and flood plain deposits.

The upper part of the Baga Formation is not exposed on Bornholm and its thickness in the Rønne Graben is about $450 \mathrm{~m}$, which is considerably greater than has been estimated previously. The boundary between the Bagå and Rabekke Formations is gradational; there does not appear to be a hiatus.

In the Rønne Graben, the Rabekke Formation is overlain by the Arnager Greensand Formation; thus the Robbedale and Jydegård Formations as recognized on Bornholm, are absent. This feature is due to differential subsidence of the blocks which has either allowed erosion or removed the Rønne Graben area from the coastal zone of sedimentation during Ryanzonian and Valanginian times (fig. 5).

The structural relationships are the result of transpressional movements which took place during the latest Cretaceous - early Tertiary, after deposition of the Bavnodde Greensand Formation. The movements resulted in inversion of the Rønne Graben and the development of a characteristic structural pattern consisting of the main eastern fault of the graben and a number of associated en échelon reverse faults. Such a structural pattern is typical of a compressive dextral strike slip regime.

Acknowledgements - This article summarizes the results obtained in connection with the search for quartz sand off the coast of Bornholm carried out by the Marine Raw Material Survey Division under the National Forest and Nature Agency, Denmark.

The authors are grateful to a number of collegues whose efforts made the project possible, and particularly to John Tychsen for positive criticism and constant support. The authors would also like to thank Mary I. Sørensen and Alice
Rosenstand for drawing the figures, and Richard Wilson for the English translation.

\section{Dansk sammendrag}

Reflektionsseismiske undersøgelser (offshore shallow seismik) har dannet grundlaget for en detaljeret geologisk kortlægning langs den østlige margin af Rønne Graven ved Bornholm.

De seismiske data er korreleret med den kendte lithostratigrafi på Bornholm, og Rønne Gravens specielle aflejringsforhold er belyst.

Rønne Gravens strukturelle forhold er ligeledes behandlet, da de detaljerede undersøgelser har givet værdifulde oplysninger, omhandlende det strukturelle mønster. Dette mønster består af Rønne Gravens østlige hovedforkastning, og et antal en échelon placerede reverse forkastninger, dannet $i$ et dextralt strike slip system.

Endelig danner de indsamlede data, suppleret med eksisterende viden, grundlag for udfærdigelsen af et kort, som viser udbredelsen af de mesozoiske formationer ved basis af kvartæret i Bornholmsområdet.

\section{References}

Atilla, A. \& Benjamin, M. 1984: Diverse Pliocene - Quaternary tectonics in a transform environment, San francisco Bay region, California. Geological Society of America Bulletin, 95, 1303-1317.

Brüsch, W. 1984: Bavnodde Grønsandets palaomiljø og -geografi. M. Sc. Thesis, Københavns Universitet, 181 pp.

Forchammer, G. 1837: Om de Bornholmske Kulformationer. Videnskab. Selskab. Naturvidenskablig-og Mathematikafhandling. VII Deel, 64 pp.

Gravesen, P., Rolle, F. \& Surlyk, F. 1982: Lithostratigraphy and sedimentary evolution of the Triassic, Jurassic and Lower Cretaceous of Bornholm, Denmark. Danmarks Geologiske Undersøgelser ser. B, 7, 1-51.

Gry, H., 1960: Geology of Bornholm. Guide to Excursions Nos A 45 and c 40. Intern. Geol. Congress XXI session Norden, $16 \mathrm{pp}$.

Gry, H., 1969: Megaspores from the Jurassic of the Island of Bornholm. Medd. dansk Geol. Foren., 19, 69-89.

Hamann, N. E., 1987a: Bornholm. Geological map of mesozoic formations. The National Forest and Nature Agency 1987.

Hamann, N. E., 1987b: Den Mesozoiske bassinudvikling ved Bornholm. M. Sc. Thesis, Københavns Universitet.

Hoelstad, T., 1985: Palynology of the uppermost Lower to Middle Jurassic strata on Bornholm, Denmark. Bull. geol. Soc. Denmark, 34, 111-132.

Jensen, J. B., 1988a: Bornholm Sydvest - en detailundersøgelse. Havbundsundersøgelser Geologi. Skov- og Naturstyrelsen.

Jensen, J. B., 1988b: Bornholm Sydvest. Detaljerede Undersøgelser. Havbundsunders $\emptyset$ gelser R\&stofprospektering. Skov- og Naturstyrelsen.

Kennedy, W. J., Hancock, J. M. and Christensen, W. K., 1980: Albian and Cenomanian ammonites from the island of Bornholm (Denmark). Bull. geol. Soc. Denmark, 29, 203244.

Larsen, B., 1986: Resultater af den rảstofgeologiske undersøgelse. In: Fredningsstyrelsen, 1986. Havbundsunders $\emptyset$ gelser. Rdstoffer og fredningsinteresser. Bornholm. Oversigt.

Liboriussen, J., Ashton, P., \& Tygesen, T., 1987: The tectonic evolution of the Fennoscandian Border Zone in Denmark. Tectonophysics, 137, 21-29. 
Noe-Nygaard, N. and Surlyk, F. 1985: Mound bedding in a sponge-rich Coniacian chalk, Bornholm, Denmark. Bull. geol. Soc. Denmark, 34, 237-249.

Noe-Nygaard, N. \& Surlyk, F., 1988: Washover fan and brackish bay sedimentation in the Berriasian-Valanginian of Bornholm, Denmark. Sedimentology 35, 197-217.

Rolle, F., Kock, J.-O., Frandsen, N. \& Surlyk, F. 1979: Jurassic environments in the Fennoscandian Border Zone. In: Sedimentation Jurassique W. Europeen A.S.F. Publication Speciale No. I Com. Geol. No. 327.

Surlyk, F. \& Noe-Nygaard, N. 1986: Humocky Cross-Strat- ification from the lower jurassic Hasle Formation of Bornholm, Denmark. Sedimentary Geology, 46, 259-273.

Vejbak, O. V. 1985: Seismic Stratigraphy and tectonics of Sedimentary Basins around Bornholm, southern Baltic. Danmarks Geol. Undersøgelser, ser. A nr. 8, 1-29.

Wilcox, R. E., Harking, T. P. \& Seely, D. R., 1973: Basic Wrench Tectonics. American Association of Petroleum Ge. ologists Bulletin. 57, 74-96.

Ziegler, P. A., 1981: Evolution of Sedimentary Basins in North West Europe. In: Illing and Hobson (eds): Petroleum Geology of the continental shelf of $N$. W. Europe. - Heyden \& Son Ltd. for 3-39. 



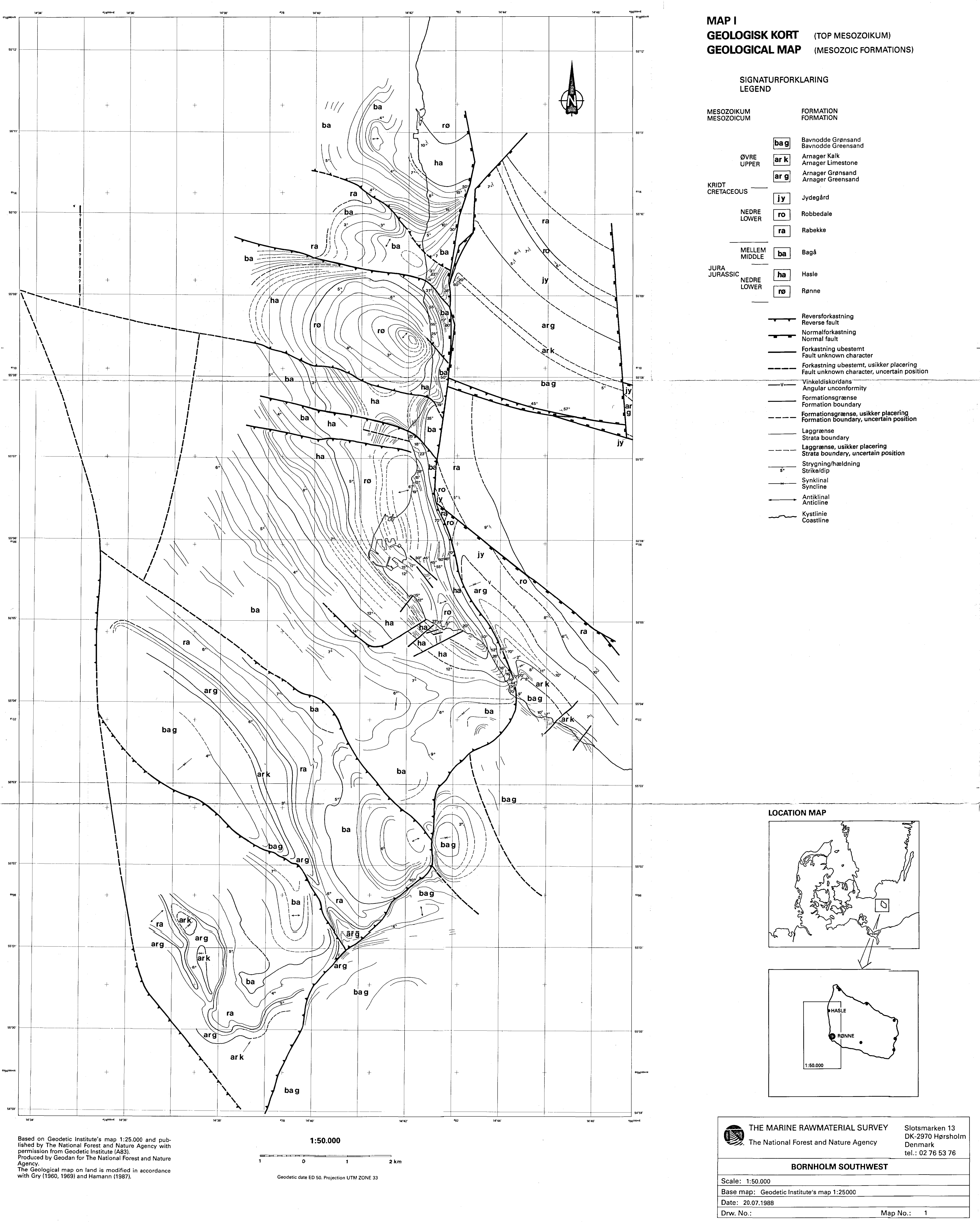

